\title{
Targeted Therapy for Older Patients with Non-Small Cell Lung Cancer: Systematic Review and Guidelines from the French Society of Geriatric Oncology (SoFOG) and the French-Language Society of Pulmonology (SPLF)/French-Language Oncology Group (GOLF)
}

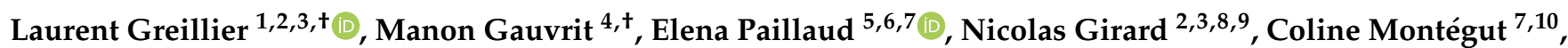
Rabia Boulahssass ${ }^{7,11,12} \mathbb{D}_{\text {, }}$ Marie Wislez ${ }^{2,3,13,14}$, Frédéric Pamoukdjian 7,15,16 $\mathbb{D}^{\mathrm{D}}$, Romain Corre ${ }^{7,17}$, Mathilde Cabart ${ }^{18}$, Philippe Caillet ${ }^{5,7,19}$, Yaniss Belaroussi 4,20,21, Matthieu Frasca 4,22,23, Pernelle Noize 4,24,25, Pascal Wang ${ }^{13}$ (D) , Soraya Mebarki ${ }^{5,7}$, Simone Mathoulin-Pelissier ${ }^{4,23}$ and Anne-Laure Couderc $7,10,26, *$ (D)

check for updates

Citation: Greillier, L.; Gauvrit, M.; Paillaud, E.; Girard, N.; Montégut, C.; Boulahssass, R.; Wislez, M.; Pamoukdjian, F.; Corre, R.; Cabart, M.; et al. Targeted Therapy for Older Patients with Non-Small Cell Lung Cancer: Systematic Review and Guidelines from the French Society of Geriatric Oncology (SoFOG) and the French-Language Society of Pulmonology (SPLF)/French-Language Oncology Group (GOLF). Cancers 2022, 14, 769. https://doi.org/10.3390/ cancers14030769

Academic Editor: Daniel S. Sitar

Received: 21 December 2021

Accepted: 29 January 2022

Published: 2 February 2022

Publisher's Note: MDPI stays neutral with regard to jurisdictional claims in published maps and institutional affiliations.

Copyright: (C) 2022 by the authors. Licensee MDPI, Basel, Switzerland. This article is an open access article distributed under the terms and conditions of the Creative Commons Attribution (CC BY) license (https:// creativecommons.org/licenses/by/ $4.0 /)$.
1 Multidisciplinary Oncology and Therapeutic Innovations Department, AP-HM Marseille France, Aix-Marseille University, CNRS INSERM CRCM, F-13009 Marseille, France; laurent.greillier@ap-hm.fr

2 French-Language Society of Pulmonology (SPLF), F-75006 Paris, France; nicolas.girard2@curie.fr (N.G.); marie.wislez@aphp.fr (M.W.)

3 French-Language Oncology Group (GOLF), F-75006 Paris, France

4 Inserm CIC1401 Institut Bergonié Clinical Research Plateform for Older Patients with Cancer (PACAN), F-33076 Bordeaux, France; m.gauvrit@bordeaux.unicancer.fr (M.G.); yaniss.belaroussi@u-bordeaux.fr (Y.B.); matthieu.frasca@chu-bordeaux.fr (M.F.); pernelle.noize@chu-bordeaux.fr (P.N.); simone.pelissier@chu-bordeaux.fr (S.M.-P.)

5 Department of Geriatrics Geriatric Oncology Clinic HEGP Paris Cancer Institute CARPEM, AP-HP, F-75015 Paris, France; elena.paillaud@aphp.fr (E.P.); philippe.caillet@aphp.fr (P.C.); soraya.mebarki@aphp.fr (S.M.)

6 Faculty of Health, Université Paris, F-75006 Paris, France

7 French Society of Geriatric Oncology (SoFOG), F-63122 Ceyrat, France; coline.montegut@ap-hm.fr (C.M.); boulahssass.r@chu-nice.fr (R.B.); frederic.pamoukdjian@aphp.fr (F.P.); romain.corre@ch-cornouaille.fr (R.C.)

8 Thorax Institute Curie-Montsouris, F-75014 Paris, France

9 UVSQ Paris, F-78000 Saclay, France

10 Internal Medicine Geriatrics and Therapeutic Unit AP-HM, F-13009 Marseille, France

11 Coordination Unit of Geriatric Oncology Rehabilitation and Autonomy Department University Hospital of Nice, F-06000 Nice, France

12 Nice Sophia Antipolis, University Onco-Age, F-06100 Nice, France

13 Oncology Thoracic Unit Pulmonology Department AP-HP Hôpital Cochin, F-75014 Paris, France; pascal.wang@aphp.fr

14 Paris University Centre de Recherche des Cordeliers, Sorbonne University INSERM Team Inflammation Complement and Cancer, F-75006 Paris, France

15 Geriatric Department APHP, Avicenne Hospital, F-93000 Bobigny, France

16 I SERM UMR_S942 Cardiovascular Markers in Stressed Conditions MASCOT, Sorbonne Paris Nord University, F-93000 Bobigny, France

17 Pulmonology Department Cornouaille Hospital, F-29000 Quimper, France

18 Oncology Department Institut Bergonié, F-33076 Bordeaux, France; m.cabart@bordeaux.unicancer.fr

19 INSERM U955 IRMB Université Paris-Est, F-94000 Créteil, France

20 Department of Thoracic Surgery Haut-Leveque Hospital Bordeaux University, University of Bordeaux, F-33000 Bordeaux, France

21 INSERM Bordeaux Population Health Research Center EPICeNE Team UMR 1219, F-33000 Bordeaux, France

22 Palliative Medicine Department CHU, F-33000 Bordeaux, France

23 Bordeaux Population Health Centre Recherche U1219, Equipe Cancer et Environnement EPICeNE, Bordeaux University, F-33000 Bordeaux, France

24 Clinical Pharmacology Department CHU Bordeaux, F-33000 Bordeaux, France

25 Univ Bordeaux INSERM BPH U1219 Team Pharmaco-Epidemiology, F-33000 Bordeaux, France

26 CNRS EFS ADES Aix-Marseille University, F-13015 Marseille, France

* Correspondence: anne-laure.couderc@ap-hm.fr; Tel.: +33(4)91-74-45-30; Fax: +33(4)91-74-48-33

+ These authors contributed equally to this work. 
Simple Summary: Targeted therapy has become essential in the treatment of non-small cell lung cancer (NSCLC). There are currently no guidelines for older patients who are frailer with regard to this type of treatment. Two learned societies, the French Society of Geriatric Oncology (SoFOG) and the French-language Society of Pulmonology (SPLF)/French-language Oncology Group (GOLF), joined forces to conduct a systematic review of the literature from May 2010 to May 2021 regarding the efficacy, toxicity, and feasibility of targeted therapy in older patients with NSCLC. Guidelines were then drawn up to enable clinicians to adapt the type of targeted therapy proposed according to the oncological and geriatric profile of the older patient with NSCLC.

\begin{abstract}
Systematic molecular profiling and targeted therapy (TKI) have changed the face of NonSmall Cell Lung Cancer (NSCLC) treatment. However, there are no specific recommendations to address the prescription of TKI for older patients. A multidisciplinary task force from the French Society of Geriatric Oncology (SoFOG) and the French Society of Pulmonology/Oncology Group (SPLF/GOLF) conducted a systematic review from May 2010 to May 2021. Protocol registered in Prospero under number CRD42021224103. Three key questions were selected for older patients with NSCLC: (1) to whom TKI can be proposed, (2) for whom monotherapy should be favored, and (3) to whom a combination of TKI can be proposed. Among the 534 references isolated, 52 were included for the guidelines. The expert panel analysis concluded: (1) osimertinib $80 \mathrm{mg} /$ day is recommended as a first-line treatment for older patients with the EGFR mutation; (2) full-dose first generation TKI, such as erlotinib or gefitinib, is feasible; (3) ALK and ROS1 rearrangement studies including older patients were too scarce to conclude on any definitive recommendations; and (4) given the actual data, TKI should be prescribed as monotherapy. Malnutrition, functional decline, and the number of comorbidities should be assessed primarily before TKI initiation.
\end{abstract}

Keywords: lung cancer; targeted therapy; efficacy; toxicity; safety; quality of life; geriatric assessment

\title{
1. Introduction
}

Lung cancer is a disease of older adults with a median age of around 70 years at the time of diagnosis [1,2] and is the leading cause of cancer death, particularly in the USA and Europe and in the elderly population [3]. However, there are very few specific guidelines relating to the treatment of lung cancer in older patients due to their underrepresentation in clinical trials [4]. As a result, older patients are treated with therapies of which the safety in use, efficacy, toxicity, and dose are based on clinical trials conducted on patients that do not reflect the older population. With age, pharmacokinetic changes [5] and frailty/comorbidities, which sometimes go hand in hand with polypharmacy, can modify the tolerance and efficacy of the molecules in this older population [6-10]. However, treatment compliance is essential to ensure treatment efficacy and avoid jeopardizing the outcome [10]. In the past ten years, the therapeutic strategy for the treatment of primary metastatic bronchial cancer has progressed rapidly, particularly with the emergence of targeted therapy as tyrosine kinase inhibitors (TKI). Systematic molecular profiling has revolutionized the treatment of patients with a genomic alteration by proposing therapy targeting the most common oncogene addiction pathways, such as EGFR, ALK, or ROS1. In recent years, numerous other oncogenic drivers that can be targeted have emerged such as BRAF, MET, RET, HER2, KRAS, NTRK, or NRG1. However, few studies have investigated these oncogenic addictions in the treatment of NSCLC [11]. According to the literature, molecular panels are proposed less frequently in older patients compared to younger patients [12]. EGFR activating mutations are found in approximately $10 \%$ of Caucasian patients [13]. A study on patients aged 80 years has shown that EGFR mutations are found in similar proportions to those in younger patients [14]. The following drugs are used for TKI in the treatment of patients with metastatic non-small cell lung cancer (NSCLC) with an EGFR mutation: gefitinib and erlotinib, which are first generation TKI, afatinib 
(2nd generation), dacomitinib (2nd generation), and osimertinib (3rd generation). ALK rearrangements are detected in $3 \%$ to $5 \%$ of patients with NSCLC [15-18]. Crizotinib (1st generation), ceritinib, alectinib, brigatinib (all 2nd generation inhibitors), and lorlatinib (3rd generation) are used in the treatment of advanced cancer with an ALK rearrangement. ROS1 rearrangements are rare (approximately 1\% of NSCLC) and are primarily diagnosed at a young age [14]. Today, crizotinib has a marketing authorization as a first-line treatment in patients with metastatic NSCLC with a ROS1 rearrangement. A combination of dabrafenib and trametinib is indicated as a first-line treatment in patients with advanced NSCLC with a BRAF V600E mutation. Mutations of the splice site of MET exon 14 are quite rare, found in 3\% to $4 \%$ of NSCLC [19]. MET mutations seem to be more common in older subjects [20-22].

The aim of the joint recommendations from the two learned societies that are the French Society of Geriatric Oncology (SoFOG) and the French-language Society of Pulmonology (SPLF)/French-language Oncology Group (GOLF) is to compile, from a literature review, data regarding the indication, efficacy, and tolerance of the TKI used in patients over 65 years with stage II, III, and IV NSCLC. The primary objective is to determine which older patients with NSCLC can be offered TKI. The secondary objectives are to decide for which older patients with NSCLC should monotherapy (TKI alone) or a combination of TKI be considered.

\section{Materials and Methods}

This systematic literature review has been registered in PROSPERO (www.crd.york.ac. uk/PROSPERO/display_record.asp?ID=CRD42021224103, accessed on 25 January 2022). Each strategy followed a standardized, declared protocol.

\subsection{Research Questions}

The research questions were formulated by a multidisciplinary group (pulmonary oncologist, geriatrician and methodologist) and are listed below:

(1) For which older patients with non-small cell lung cancer (NSCLC) can we propose the following TKI: EGFR tyrosine kinase inhibitors, ALK tyrosine kinase inhibitors, ROS1 tyrosine kinase inhibitors, and inhibitors of other molecular alterations BRAF/MET?

(2) For which older patients with NSCLC must we consider mono-therapy (TKI alone)?

(3) For which older patients with NSCLC can we consider a combination of several TKI?

\subsection{Inclusion and Exclusion Criteria}

The articles included were (1) trials or observational studies or systematic reviews or meta-analyses, (2) stage II, III, or IV NSCLC, (3) older patients (65 years or over, 70 years or over, 75 years or over, or 80 years or over) mentioned in the title or abstract, (4) outcomes: Overall survival (OS), progression-free survival (PFS), disease-free survival (DFS), treatment and/or treatment feasibility and/or treatment complications and/or toxicity, quality of life, G8 screening score, or data from Comprehensive Geriatric Assessments (CGA).

We chose to exclude narrative reviews, case series, clinical cases, comments, and opinions.

\subsection{Data and Research Algorithm}

The research was conducted between May 2010 and May 2020. The literature was monitored until the paper was written (May 2021). Medline, Cochrane Database, and Embase were queried. The MeSH terms used are listed in the Supplementary Data (Figure S1).

\subsection{Article Selection}

A group comprising a pulmonary oncologist, a geriatrician, and a methodologist independently read the titles and abstracts of the articles included and coded the references "yes" (to be included), "no" (not to be included), or "uncertain". Any discrepancies, particularly regarding "uncertain" articles, were discussed at a consensus meeting. All decisions made by the members of the coordination group, and, more particularly, the 
discrepancies and references included, were documented. The selected articles were divided equally between five work groups, each comprising a (pulmonary) oncologist, a geriatrician, and a methodologist. They read all the articles assigned and decided whether they should be included in the review or not, the data to be studied, and any study bias. All the decisions made by the members of the work group were documented. A standardized grid was created. To assess bias, the Cochrane grid was used for randomized trials [23]. The study selection process presented above is documented in a flow diagram based on the PRISMA (Preferred Reported Items for Systematic Reviews and Meta-Analyses) reporting guidelines endorsed by INESSS [24]. Ranking of guidelines are based on HAS 2013, and a descriptive table of the recommendation staging (grade A, B, or C) is available in Table S1) [25].

\section{Results}

The literature search identified 534 references in three databases (Pubmed, Cochrane, and Scopus) and 14 external references (articles previously published by members of this work group). A further 295 abstracts and 98 articles to be read by the groups were identified after full reading meta-analysis and reviews and after revision between April 2020 and May 2021. Ultimately, 52 articles were included (cf. flow chart in Figure 1).

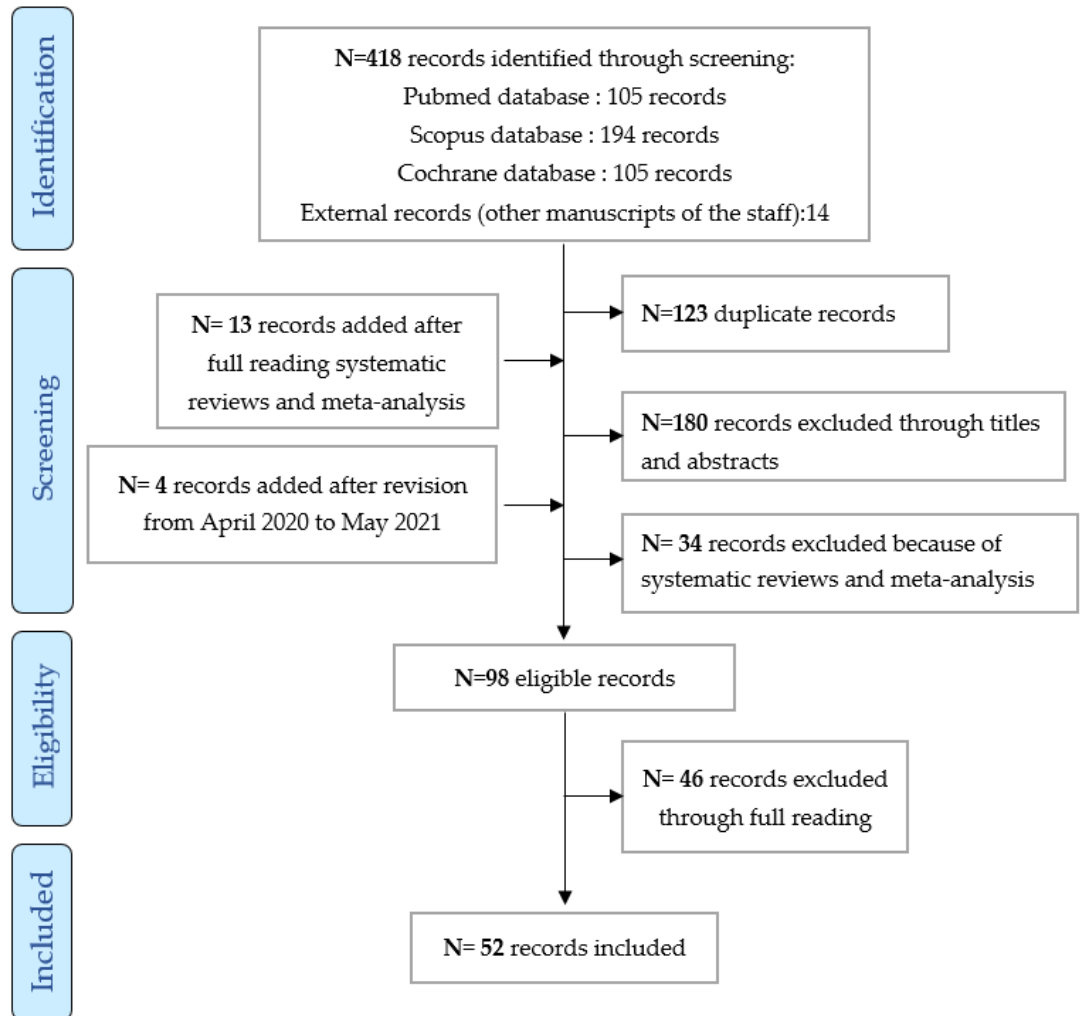

Figure 1. Inclusion diagram of the studies analyzed from May 2010 to May 2021.

To answer the 3 questions predefined in the methodology, we included:

- 28 articles on the efficacy of EGFR TKI (only articles mentioning the mutation were included: 17 prospective observational and retrospective non-randomized studies dedicated to older subjects [26-42], and 11 prospective randomized or non-randomized studies not dedicated to older subjects [43-53]; 5 articles on the efficacy of ALK TKI were analyzed: 2 prospective non-randomized observational studies not dedicated to older subjects (subgroup of older subjects) and 3 randomized prospective studies not dedicated to older subjects (subgroup of older subjects) [16,17,54-56]; only one study on the efficacy of ROS1 TKI as crizotinib was included [57]. 
- 36 articles on toxicity: 26 retrospective or prospective studies specific to older subjects [26-40,42,58-67], 5 randomized studies dedicated to older subjects [7,68-71], 4 prospective studies with a subgroup of older subjects [55,72-74], and a randomized study including a subgroup of older subjects [44].

- 36 articles on feasibility: 26 prospective and retrospective studies, 4 prospective studies with a subgroup of older subjects, 5 randomized studies specific to older subjects, and a randomized study with a subgroup of older subjects.

- $\quad$ four articles on quality of life $[31,33,69,75]$ and 7 studies on geriatric data $[36,41,42,66,71,74,76]$.

\subsection{Efficacy}

In the literature, the number of studies in older patients with dabrafenib/trametinib/ vemurafenib/capmatinib/merestinib/savolitinib/lorlatinib/nintedanib/tepotinib/repotrectinib/ pralsetinib/selpercatinib/alectinib/brigatinib/entrectinib/larotrectinib were limited.

\subsubsection{EGFR Tyrosine Kinase Inhibitors}

Prospective and retrospective cohort studies were specifically dedicated to older subjects ( $\geq 65$ years) (Table 1$)$.

In older patients treated with osimertinib (80 mg/day [38-40]), the median overall survival varied from 19.4 to 38.6 months. In another objective response rate (ORR) varied from $56.5 \%$ to $61 \%$, the median progression-free survival (PFS) varied from 6.4 to 17.7 months, and, in Furuta et al. [37], no significant difference was observed for PFS and OS between older subjects and younger subjects treated with osimertinib. In older patients treated with gefitinib (250 mg/day) [29-31,34,36], the ORR varied from $45.5 \%$ to $74.2 \%$, PFS varied from 10.0 to 14.3 months, and OS varied from 19 to 33.8 months. PFS with gefitinib was homogenous (varying from 10.0 to 14.3 months), but OS varied due to the various regimens ranging from first-line therapy to other advanced lines of treatment. The same applied to osimertinib, with which PFS varied due to the different regimens; most of the studies included were anterior to the use of osimertinib as a first-line treatment.

For erlotinib (150 mg/day) [41,42], the ORR varied from 56.3\% to $60.0 \%$, and PFS varied from 9.3 to 15.5 months.

For afatinib (40 mg/day) [28], the median PFS and OS were longer in patients with a lower dose (30 patients) compared to the other patients (8 patients) (PFS: 16.9 versus 3.5 months, HR 0.2, $p=0.001$; OS: NR (not reached) versus 10.3 months, HR 0.09, $p<0.001$ ). For a dose of $30 \mathrm{mg}$ /day of afatinib [26,27], the ORR was 72.5\% and PFS 12.9 months. The results are hard to interpret as there are very few studies assessing TKI as a first-line treatment. Osimertinib was not superior to the other TKI in the different studies. OS with osimertinib seemed to be shorter in these studies than the general population, but patients were mainly on second-line therapy or beyond. There is very little data for older patients with a Performance Status (PS) $\geq 2$.

Prospective randomized or non-randomized studies not dedicated to older subjects (subgroup of older subjects) are shown in Table 2.

In older patients treated with osimertinib (80 mg/day) [51], a lower risk of progression was observed (similar to younger patients; HR 0.38). Two phase 3 studies [49,50] comparing osimertinib (80 mg/day) and gefitinib (250 mg/day) or erlotinib (150 mg/day) reported similar benefits in terms of PFS and OS with osimertinib in older subjects (as with younger subjects). In older patients treated with gefitinib (250 mg/day) or afatinib (40 mg/day), in three studies [43,44,53], PFS was in favor of afatinib in the group of subjects $\geq 65$ years [43], and PFS and OS were better with afatinib compared to gefitinib for patients $\geq 75$ years (as with younger patients) [44]. In Sequist et al. [45] (afatinib $40 \mathrm{mg} /$ day versus chemotherapy), PFS (HR 0.64, 95\% CI, 0.39 to 1.03, $p=0.58$ ) favored afitinib for patients < 65 years, as well as patients $\geq 65$ years. In two studies [47,48], PFS favored erlotinib (150 mg/day versus chemotherapy) as with younger patients. Comparing dacomitinib ( $45 \mathrm{mg} /$ day) with gefitinib (250 mg/day), PFS favored dacomitinib for patients $\geq 65$ years (HR 0.69, 95\% CI, 0.48 to 0.99 ), as with patients $<65$ years [46]. 
Table 1. Targeted therapy efficacy results in older patients in retrospective and prospective cohorts ( $\geq 65$ years).

\begin{tabular}{|c|c|c|c|c|c|c|c|}
\hline $\begin{array}{l}\text { Publication/ } \\
\text { Country }\end{array}$ & $\begin{array}{l}\text { Targeted } \\
\text { Therapy }\end{array}$ & $\begin{array}{l}\text { Patient } \\
\text { Number }\end{array}$ & $\begin{array}{l}\text { ECOG-PS } \\
\geq 2(\%)\end{array}$ & $\begin{array}{l}\text { Median Age, } \\
\text { Years }\end{array}$ & $\begin{array}{l}\text { Objective } \\
\text { Tumor } \\
\text { Response (95\% CI) }\end{array}$ & $\begin{array}{l}\text { Median PFS, } \\
\text { Months } \\
(95 \% \text { CI })\end{array}$ & $\begin{array}{l}\text { Median OS, } \\
\text { Months } \\
(95 \% \text { CI })\end{array}$ \\
\hline $\begin{array}{l}\text { Tanaka } 2018 \\
\text { [26]/Japan }\end{array}$ & $\begin{array}{l}\text { Afatinib } \\
40 \mathrm{mg} / \text { day } \\
30 \mathrm{mg} / \text { day } \\
20 \mathrm{mg} / \text { day }\end{array}$ & 15 & 13.3 & 79 & 73.3 (NR) & 22 (13.1-NR) & \\
\hline Imai 2018 [27]/Japan & $\begin{array}{l}\text { Afatinib } \\
30 \mathrm{mg} / \text { day }\end{array}$ & 40 & 2.5 & 77 & $72.5(58.6-86.3)$ & $12.9(8.8-19.3)$ & $\begin{array}{l}\text { NR } \\
\text { At } 1 \text { year: } 87.4 \% \text {, } \\
2 \text { years: } 60.6 \%\end{array}$ \\
\hline $\begin{array}{l}\text { Minegishi } 2021 \\
\text { [28]/Japan }\end{array}$ & $\begin{array}{l}\text { Afatinib } \\
40 \mathrm{mg} / \text { day }\end{array}$ & 37 & 0 & 77.5 & $75.7(58.8-88.2)$ & $14.2(9.5-19.0)$ & $\begin{array}{l}35.2(35.2-\mathrm{NR}) \\
\text { At } 1 \text { year: } 83.8 \% \text {, } \\
2 \text { years: } 78.3 \%\end{array}$ \\
\hline $\begin{array}{l}\text { Tateishi } 2013 \\
\text { [29]/Japan }\end{array}$ & $\begin{array}{l}\text { Gefitinib } \\
250 \mathrm{mg} / \text { day }\end{array}$ & 55 & 16.4 & 81.1 & $72.7(59.5-82.9)$ & $13.8(9.9-18.8)$ & $\begin{array}{l}29.1(22.4-N R) \\
\text { At } 2 \text { years: } 59.5 \%\end{array}$ \\
\hline $\begin{array}{l}\text { Fujita } 2012 \\
{[30] / J a p a n}\end{array}$ & $\begin{array}{l}\text { Gefitinib } \\
250 \mathrm{mg} / \text { day }\end{array}$ & 54 & 0 & 81 & $45.5(24.4-67.8)$ & & $\begin{array}{l}27.9 \\
\text { At } 1 \text { year: } 90 \%\end{array}$ \\
\hline $\begin{array}{l}\text { Morikawa } 2015 \\
\text { [31]/Japan }\end{array}$ & $\begin{array}{l}\text { Gefitinib } \\
250 \mathrm{mg} / \text { day } \\
\text { versuscaboplatine/ } \\
\text { paclitaxel }\end{array}$ & 71 & 8 & 75 & $73.2(61.3-83.0)$ & 14.3 & 30.8 \\
\hline $\begin{array}{l}\text { Maemondo } 2012 \\
\text { [32]/Japan }\end{array}$ & $\begin{array}{l}\text { Gefitinib } \\
250 \mathrm{mg} / \text { day }\end{array}$ & 31 & 6 & 80.3 & $74.2(57.9-90.5)$ & 12.1 & $\begin{array}{l}33.8 \\
\text { At } 1 \text { year: } 83.9 \% \text {, at } \\
2 \text { years: } 58.1\end{array}$ \\
\hline $\begin{array}{l}\text { Takahashi } 2014 \\
\text { [33]/Japan }\end{array}$ & $\begin{array}{l}\text { Gefitinib } \\
250 \mathrm{mg} / \text { day }\end{array}$ & 20 & 10 & 79.5 & $70(45.7-88.1)$ & 10.0 & 26.4 \\
\hline $\begin{array}{l}\text { Kuwako } 2015 \\
\text { [34]/Japan }\end{array}$ & $\begin{array}{l}\text { Gefitinib } \\
250 \mathrm{mg} / \text { day }\end{array}$ & 62 & 29 & 80 & 61.3 & 13.2 & 19 \\
\hline $\begin{array}{l}\text { Asami } 2011 \\
\text { [35]/Japan }\end{array}$ & $\begin{array}{l}\text { Gefitinib } \\
250 \mathrm{mg} / \text { day }\end{array}$ & 17 & 17 & 81 & $59(33-81)$ & $12.9(2.2-23.6)$ & $\begin{array}{l}\text { OS }(\mathrm{NR}) \\
\text { At } 1 \text { year: } 88 \%\end{array}$ \\
\hline $\begin{array}{l}\text { Corre } 2018 \\
\text { [36]/France }\end{array}$ & $\begin{array}{l}\text { Gefitinib or } \\
\text { erlotinib or afatinib }\end{array}$ & 114 & 28.4 & 83.9 & 63.3 & $11.9(8.6-14.7)$ & $20.9(14.3-27.1)$ \\
\hline $\begin{array}{l}\text { Furuta } 2018 \\
\text { [37]/Japan }\end{array}$ & Osimertinib & 18 & 0 & 80 & 61 & 17.7 (8.4-NR) & $38.6(14.3-52.8)$ \\
\hline $\begin{array}{l}\text { Nakao } 2020 \\
\text { [38]/Japan }\end{array}$ & $\begin{array}{l}\text { Osimertinib } \\
80 \mathrm{mg} / \text { day }\end{array}$ & 36 & 0 & 80 & $58.3(42.2-72.9)$ & $11.9(7.9-17.5)$ & $\begin{array}{l}22.0(16.0-\mathrm{NR}) \text { at } \\
1 \text { year: } 77.8 \% \text {, at } \\
2 \text { years: } 49.5 \%\end{array}$ \\
\hline $\begin{array}{l}\text { Auliac } 2019 \\
\text { [39]/France }\end{array}$ & $\begin{array}{l}\text { Osimertinib } \\
80 \mathrm{mg} / \text { day }\end{array}$ & 43 & 42.4 & 84.6 & & $17.5(12.2-19.0)$ & 22.8 (15.7-NR) \\
\hline \multirow{3}{*}{ Kato 2019 [40]/Japan } & \multirow{3}{*}{ Osimertinib } & 31 & 10 & 32.3 & & $5.6(3.6-14.8)$ & 19.4 (9.1-NR) \\
\hline & & 8 & 3 & 54 & & $3.5(1.6-14.8)$ & 5.3 \\
\hline & & 23 & 7 & 75 & & $\begin{array}{l}6.4(5-\mathrm{NR}) \\
\text { HR } 2.41 ; p=0.041\end{array}$ & $\begin{array}{l}19.4 \\
\text { HR } 2.58 ; p=0.067\end{array}$ \\
\hline $\begin{array}{l}\text { Miyamoto } 2020 \\
\text { [41]/Japan }\end{array}$ & $\begin{array}{l}\text { Erlotinib } \\
50 \mathrm{mg} / \text { day }\end{array}$ & 80 & 32 & 80 & $60.0(50.2-69.2)$ & $9.3(7.2-11.4)$ & $26.2(21.9-30.4)$ \\
\hline $\begin{array}{l}\text { Inoue } 2015 \\
\text { [42]/Japan }\end{array}$ & $\begin{array}{l}\text { Erlotinib } \\
150 \mathrm{mg} / \text { day }\end{array}$ & 32 & 3.1 & 80 & $56.3(39.4-72.0)$ & 15.5 (11.2-NR) & $\begin{array}{l}\text { Median OS (NR) } \\
\text { At } 1 \text { year: } 83.9 \% \\
(65.5-93.0)\end{array}$ \\
\hline
\end{tabular}

HR: hazard ratio; ECOG-PS: eastern cooperative oncology group-performance status; NR: not reached; PFS: progression-free survival; OS: overall survival. For each treatment, when several studies express results as medians with intervals, the minimum and maximum medians observed are reported in the table. When there is only one study for a given treatment, the median with its interval is reported in the table.

Table 2. Targeted therapy efficacy results in older patients in randomized or non-randomized trials (subgroup post-hoc analysis).

\begin{tabular}{|c|c|c|c|c|c|c|}
\hline $\begin{array}{l}\text { Publication/ } \\
\text { Country }\end{array}$ & $\begin{array}{l}\text { Targeted } \\
\text { Therapy }\end{array}$ & $\begin{array}{l}\text { Patients } \\
\text { Number }\end{array}$ & $\begin{array}{l}\text { Age } \\
\text { Group }\end{array}$ & $\begin{array}{l}\text { ECOG-PS } \\
\geq 2(\%)\end{array}$ & $\begin{array}{l}\text { PFS (Months) } \\
\text { (95\% CI) }\end{array}$ & $\begin{array}{l}\text { OS (Months) } \\
\text { (95\% CI) }\end{array}$ \\
\hline \multirow{2}{*}{$\begin{array}{l}\text { Park } 2016 \text { [43]/ } \\
\text { International }\end{array}$} & \multirow{2}{*}{$\begin{array}{l}\text { Afatinib } \\
40 \mathrm{mg} / \text { day } \\
\text { or gefitinib } \\
250 \mathrm{mg} / \text { day }\end{array}$} & 319 & & 0 & & \\
\hline & & 177 & $<65$ & & $\begin{array}{l}\text { afatinib } 11.0 \\
(9.2-17.0) \\
\text { gefitinib } 9.2 \\
(7.3-11.0) \\
\text { HR } 0.68(0.48-0.97)\end{array}$ & \\
\hline
\end{tabular}


Table 2. Cont.

\begin{tabular}{|c|c|c|c|c|c|c|}
\hline $\begin{array}{l}\text { Publication/ } \\
\text { Country }\end{array}$ & $\begin{array}{l}\text { Targeted } \\
\text { Therapy }\end{array}$ & $\begin{array}{l}\text { Patients } \\
\text { Number }\end{array}$ & $\begin{array}{l}\text { Age } \\
\text { Group }\end{array}$ & $\begin{array}{l}\text { ECOG-PS } \\
\geq 2(\%)\end{array}$ & $\begin{array}{l}\text { PFS (Months) } \\
(95 \% \mathrm{CI})\end{array}$ & $\begin{array}{l}\text { OS (Months) } \\
(95 \% \mathrm{CI})\end{array}$ \\
\hline & & 142 & $\geq 65$ & & $\begin{array}{l}\text { afatinib } 11.0 \\
(9.2-12.9) \\
\text { gefitinib } 11.4 \\
(10.8-12.9) \\
\text { HR } 0.85(0.59-1.22) ; \\
p=0.309\end{array}$ & \\
\hline \multirow{3}{*}{$\begin{array}{l}\text { Wu } 2018 \text { [44]/ } \\
\text { International }\end{array}$} & \multirow{3}{*}{$\begin{array}{l}\text { Afatinib } 40 \mathrm{mg} / \text { day } \\
\text { or gefitinib } 250 \mathrm{mg} / \text { day }\end{array}$} & 319 & & 0 & & \\
\hline & & 177 & $<75$ & & $\begin{array}{l}\text { Afatinib } 11.0 \\
\text { Gefitinib } 10.9 \\
\text { HR } 0.76(0.58-1.00)\end{array}$ & $\begin{array}{l}\text { Afatinib } 28.9 \\
\text { Gefitinib } 25.2 \\
\text { HR } 0.85(0.64-1.12)\end{array}$ \\
\hline & & 142 & $\geq 75$ & & $\begin{array}{l}\text { Afatinib } 14.7 \\
\text { Gefitinib } 10.8 \\
\text { HR } 0.69(0.33-1.44)\end{array}$ & $\begin{array}{l}\text { Afatinib } 27.9 \\
\text { Gefitinib } 19.7 \\
\text { HR } 1.05(0.5-2.21)\end{array}$ \\
\hline \multirow{3}{*}{$\begin{array}{l}\text { Paz-Ares } 2017 \\
\text { [53]/International }\end{array}$} & \multirow{3}{*}{$\begin{array}{l}\text { Afatinib } \\
40 \mathrm{mg} / \text { day or } \\
\text { gefitinib } 250 \mathrm{mg} / \text { day }\end{array}$} & 319 & & 0 & & \\
\hline & & 177 & $<65$ & & & \multirow{2}{*}{$\begin{array}{l}0.66(0.46-0.94) \\
\text { HR } 1.22(0.82-1.81) \\
p=0.0228\end{array}$} \\
\hline & & 142 & $\geq 65$ & & & \\
\hline \multirow{3}{*}{$\begin{array}{l}\text { Sequist } 2013 \text { [45]/ } \\
\text { International }\end{array}$} & \multirow{3}{*}{$\begin{array}{l}\text { Afatinib } \\
40 \mathrm{mg} / \text { day or } \\
\text { cisplatine/pemetrexed }\end{array}$} & 345 & & & & \\
\hline & & 211 & $<65$ & & HR $0.53(0.36-0.76)$ & \\
\hline & & 134 & $\geq 65$ & & $\begin{array}{l}\text { HR } 0.64 \text { (0.39-1.03); } \\
p=0.58\end{array}$ & \\
\hline \multirow{3}{*}{$\begin{array}{l}\text { Wu } 2017 \\
\text { [46]/International }\end{array}$} & \multirow{3}{*}{$\begin{array}{l}\text { Dacomitinib } 45 \mathrm{mg} / \text { day } \\
\text { or gefitinib } \\
250 \mathrm{mg} / \text { day }\end{array}$} & 452 & & 0 & & \\
\hline & & $\begin{array}{l}\text { dacomitinib/ } \\
\text { gefitinib }\end{array}$ & $<65$ & & HR $0.51(0.39-0.69)$ & \\
\hline & & $\begin{array}{l}\text { dacomitinib/ } \\
\text { gefitinib }\end{array}$ & $\geq 65$ & & HR 0.69 (0.48-0.99) & \\
\hline \multirow{3}{*}{$\begin{array}{l}\text { Zhou } 2011 \\
\text { [47]/China }\end{array}$} & \multirow{3}{*}{$\begin{array}{l}\text { Erlotinib } 150 \mathrm{mg} \text { /dayor } \\
\text { gemcitabine/cisplatin }\end{array}$} & 165 & & 9 & & \\
\hline & & 64 & $<65$ & & HR $0.19(0.11-0.31)$ & \\
\hline & & 19 & $\geq 65$ & & HR 0.17 (0.07-0.43) & \\
\hline \multirow{3}{*}{$\begin{array}{l}\text { Rosell } 2012 \\
\text { [48]/International }\end{array}$} & \multirow{3}{*}{$\begin{array}{l}\text { Erlotinib } 150 \mathrm{mg} / \text { day or } \\
\text { cisplatin/docetaxel or } \\
\text { gemcitabin }\end{array}$} & 173 & & 14 & & \\
\hline & & 85 & $<65$ & & HR $0.44(0.25-0.75)$ & \\
\hline & & 88 & $\geq 65$ & & $\begin{array}{l}\text { HR } 0.28(0.16-0.51) \\
p=0.4962\end{array}$ & \\
\hline \multirow{3}{*}{$\begin{array}{l}\text { Soria } 2018 \\
\text { [49]/International }\end{array}$} & \multirow{3}{*}{$\begin{array}{l}\text { Osimertinib } 80 \mathrm{mg} / \text { day or } \\
\text { gefitinib } 250 \mathrm{mg} \text { /day or } \\
\text { erlotinib } 150 \mathrm{mg} / \text { day }\end{array}$} & 556 & & 0 & & \\
\hline & & 298 & $<65$ & & HR 0.44 (0.33-0.58) & \\
\hline & & 258 & $\geq 65$ & & HR $0.49(0.35-0.67)$ & \\
\hline \multirow{3}{*}{$\begin{array}{l}\text { Ramalingam } 2020 \\
\text { [50]/International }\end{array}$} & \multirow{3}{*}{$\begin{array}{l}\text { Osimertinib } 80 \mathrm{mg} / \text { day or } \\
\text { gefitinib } 250 \mathrm{mg} \text { /day or } \\
\text { erlotinib } 150 \mathrm{mg} / \text { day }\end{array}$} & 556 & & 0 & & \\
\hline & & 298 & $<65$ & & & HR $0.72(0.54-0.97)$ \\
\hline & & 258 & $\geq 65$ & & & HR 0.87 (0.63-1.22) \\
\hline \multirow{3}{*}{$\begin{array}{l}\text { Mok } 2017[51] / \\
\text { International }\end{array}$} & \multirow{3}{*}{$\begin{array}{l}\text { Osimertinib } \\
80 \mathrm{mg} / \text { day }\end{array}$} & 279 & & & & \\
\hline & & 242 & $<65$ & & HR 0.38 (0.28-0.54) & \\
\hline & & 177 & $\geq 65$ & & HR $0.34(0.23-0.50)$ & \\
\hline \multirow{3}{*}{$\begin{array}{l}\text { Douillard } 2014 \\
\text { [52]/International }\end{array}$} & \multirow{3}{*}{$\begin{array}{l}\text { Gefitinib } \\
250 \mathrm{mg} / \text { day }\end{array}$} & 106 & & 6.6 & & \\
\hline & & 55 & $\leq 65$ & & $65.5(52.3-76.6)$ & \\
\hline & & 51 & $>65$ & & $74.5(61.1-84.5)$ & \\
\hline
\end{tabular}

HR: hazard ratio; ECOG-PS: eastern cooperative oncology group-performance status; NR: not reached; PFS: progression-free survival; OS: overall survival. For each treatment, when several studies express results as medians with intervals, the minimum and maximum medians observed are reported in the table. When there is only one study for a given treatment, the median with its interval is reported in the table.

Thus, in patients with an EGFR activating mutation, the efficacy of anti-EGFR TKI in terms of ORR, PFS, and OS seems similar in patients aged $\geq 65$ years (even over 75 years) and younger patients. In older patients, all lines and molecules included, ORR varied from $45.5 \%$ to $75.7 \%$, PFS varied from 6.4 to 22 months, and OS varied from 19 to 38.6 months. PFS and OS were in favor of osimertinib as a first-line treatment in older subjects (as with younger subjects) compared to first generation TKI (erlotinib and gefitinib). In the case of a T790M mutation, osimertinib was more effective as a second-line treatment than 
platinum-based chemotherapy in terms of PFS (no data on OS). However, this greater efficacy needs to be weighed up against the toxicity results of osimertinib in this older population. There are probably few indications for the use of first generation TKI in the case of an EGFR mutation: Erlotinib and afatinib are more effective as first-line treatments than platinum-based chemotherapy in terms of PFS whatever the age (no data on OS). Afatinib is more effective than gefitinib as a first-line treatment in terms of PFS and OS, with an efficacy that seems greater in patients who had a decrease in dose. Dacomitinib is more effective than gefitinib as a first-line treatment in terms of PFS only but is not very pertinent in clinical practice.

\subsubsection{ALK Tyrosine Kinase Inhibitors in Older Subjects}

In two randomized phase 3 studies with a subgroup of patients aged $\geq 65$ years and $\geq 75$ years [16,54], a better PFS was obtained in the alectinib arm (300 mg twice/day or $600 \mathrm{mg}$ twice/day) compared to crizotinib (250 mg twice/day). A Phase 1 study [56] including treatment with crizotinib (250 mg twice/day) showed an ORR very similar to that of younger patients. Another observational study comparing crizotinib, ceritinib, and alectinib [55] revealed similar PFS and OS with no significant difference in patients $\geq 65$ years versus patients $<65$ years. Finally, an article comparing ceritinib with chemotherapy (cisplatine and pemetrexed) [17] showed PFS in favor of ceritinib (750 mg/day), as with younger patients. However, the results must be weighed up against the fact that, from an epidemiological viewpoint, very few older patients have the ALK mutation (3\% to 5\% of patients with NSCLC) (Table 3).

Table 3. Targeted therapy efficacy results in older patients in randomized or non-randomized trials (subgroup post-hoc analysis).

\begin{tabular}{|c|c|c|c|c|c|c|c|}
\hline $\begin{array}{l}\text { Publication/ } \\
\text { Country }\end{array}$ & $\begin{array}{l}\text { Targeted } \\
\text { Therapy }\end{array}$ & $\begin{array}{l}\text { Patient } \\
\text { Number }\end{array}$ & $\begin{array}{l}\text { Age } \\
\text { Group }\end{array}$ & $\begin{array}{l}\text { ECOG-PS } \\
\geq 2(\%)\end{array}$ & $\begin{array}{l}\text { Objective } \\
\text { Response Rate } \\
(95 \% \text { CI) }\end{array}$ & $\begin{array}{l}\text { PFS (Months) } \\
\text { (95\% CI) }\end{array}$ & $\begin{array}{l}\text { OS (Months) } \\
(95 \% \mathrm{CI})\end{array}$ \\
\hline \multirow{3}{*}{$\begin{array}{l}\text { Hida } 2017[54] / \\
\text { Japan }\end{array}$} & \multirow{3}{*}{$\begin{array}{l}\text { Alectinib } 300 \mathrm{mg} \text { twice } \\
\text { a day } \\
\text { or crizotinib } 250 \mathrm{mg} \\
\text { twice a day }\end{array}$} & 207 & & 2 & & & \\
\hline & & 185 & $<75$ & & & HR $0.34(0.21-0.56)$ & \\
\hline & & 22 & $\geq 75$ & & & HR 0.28 (0.06-1.19) & \\
\hline \multirow{3}{*}{$\begin{array}{l}\text { Peters } 2017 \text { [16]/ } \\
\text { International }\end{array}$} & \multirow{3}{*}{$\begin{array}{l}\text { Alectinib } \\
600 \mathrm{mg} \text { twice a day } \\
\text { or crizotinib } 250 \mathrm{mg} \\
\text { twice a day }\end{array}$} & 303 & & 7 & & & \\
\hline & & 233 & $<65$ & & & HR $0.48(0.34-0.70)$ & \\
\hline & & 70 & $\geq 65$ & & & HR 0.45 (0.24-0.87) & \\
\hline \multirow{3}{*}{$\begin{array}{l}\text { Camidge } 2012 \\
\text { [56]/International }\end{array}$} & \multirow{3}{*}{$\begin{array}{l}\text { Crizotinib } \\
250 \mathrm{mg} \text { twice a day }\end{array}$} & 149 & & 12 & & & \\
\hline & & 123 & $<65$ & & $60.2(50.9-68.9)$ & & \\
\hline & & 20 & $\geq 65$ & & $65.0(40.8-84.6)$ & & \\
\hline \multirow{3}{*}{$\begin{array}{l}\text { Soria } 2017 \text { [17]// } \\
\text { International }\end{array}$} & \multirow{3}{*}{$\begin{array}{l}\text { Ceritinib } \\
750 \mathrm{mg} / \text { day } \\
\text { or cisplatin/pemetrexed }\end{array}$} & 376 & & 0 & & & \\
\hline & & 295 & $<65$ & & & $\begin{array}{l}17.1(12.5-27.7) \\
\text { HR } 0.58(0.42-0.80)\end{array}$ & \\
\hline & & 81 & $\geq 65$ & & & $\begin{array}{l}14.0(8.3-N R) \\
\text { HR } 0.45(0.24-0.86)\end{array}$ & \\
\hline \multirow{3}{*}{$\begin{array}{l}\text { Bedas } 2019 \text { [55]/ } \\
\text { Israel }\end{array}$} & \multirow{3}{*}{$\begin{array}{l}\text { Crizotinib or alectinib } \\
\text { or ceritinib }\end{array}$} & 53 & & 11 & & crizotinib $5.6(2.5-14.7)$ & $25.1(10.8-53.6)$ \\
\hline & & 34 & $<65$ & & & ceritinib $23(0.8-27.7)$ & \\
\hline & & 19 & $\geq 65$ & & & alectinib 5.6 (0.5-NR) & \\
\hline
\end{tabular}

HR: hazard ratio; ECOG-PS: eastern cooperative oncology group-performance status; NR: not reached; PFS progression-free survival; OS: overall survival. For each treatment, when several studies express results as medians with intervals, the minimum and maximum medians observed are reported in the table. When there is only one study for a given treatment, the median with its interval is reported in the table.

It is difficult to draw any conclusions due to the low number of studies dedicated to older subjects. Nevertheless, the efficacy of anti-ALK TKI in terms of ORR, PFS, and OS seems similar in patients aged 65 years and over and in younger subjects. In terms of PFS, alectinib is more effective than crizotinib as a first- or second-line treatment, whatever the age. In terms of PFS, ceritinib is more effective than platinum-based chemotherapy drugs as a first-line treatment, whatever the age (no data on OS). 


\subsubsection{ROS1 Tyrosine Kinase Inhibitors in Older Subjects, Case of the Crizotinib}

We found one non-randomized observational phase 2 study [57] including 127 patients of Asian origin with a ROS1 mutation treated with crizotinib (250 $\mathrm{mg}$ twice/day) as a fourth-line treatment or no longer receiving treatment. The study was conducted from 2013 to 2015 , and the median age was 51.5 years. Twenty-one patients $(16.5 \%)$ were $\geq 65$ years, and the ORR was $61.9 \%$ (95\% CI, 38.4 to 81.9 ), which is 13 out of 21 patients. In comparison, the ORR for younger patients was $73.6 \%$. Age had no significant effect on clinical efficacy, and there is no argument to consider that the efficacy of crizotinib in patients with an ROS1 rearrangement would differ depending on age.

\subsubsection{Erlotinib Combined with Bevacizumab in Older Subjects}

A randomized, multicentric phase 2 study [66] was carried out in Japan from 2015 to 2018 on 25 patients $\geq 75$ years treated with a combination of erlotinib $(150 \mathrm{mg} /$ day $)$ and bevacizumab as a first-line treatment. There was a partial response in $88 \%$ of cases $(95 \% \mathrm{CI}$, 74 to 99 ), stability in $12 \%$ of cases, and, therefore, control of the disease in $100 \%$ of cases ( $95 \%$ CI; 88.7 to $100 \%$ ). PFS was 12.6 months (95\% CI; 8.0 to -33.7 ), and the median survival was not reached (OS NR; 95\% CI; 34.0 months-NR). There is not enough data to draw up specific recommendations (only one phase 2 study). The results need to be weighed up against the toxicity induced by bevacizumab.

\subsection{Toxicity}

Tables 4 and 5 .

\subsubsection{EGFR Tyrosine Kinase Inhibitors}

- Afatinib (40 mg/day, except in Wu et al. [44], in which there were 3 doses: $40 \mathrm{mg} /$ day, $30 \mathrm{mg} /$ day, and $20 \mathrm{mg}$ /day) [26-28,36,44]:

The different studies show the good tolerance of afatinib from a hematological viewpoint. Grade 3-4 cytopenia was observed in less than $4 \%$ of cases in the studies. Grade 3-4 hematological toxicities most commonly observed in older subjects treated with afatinib (affecting almost one third of patients in the studies) were mucositis ( $3 \%$ to $50 \%)$, diarrhea ( $8 \%$ to $33 \%)$, skin rash ( $5 \%$ to $33 \%$ ), paronychia ( $5 \%$ to $28 \%$ ), and asthenia ( $1 \%$ to $33 \%$ ). These proportions are higher than in the general population. Likewise, the probability of developing interstitial lung disease is higher in older patients (5\% to 10\%). Low-grade digestive toxicities, skin toxicities, and asthenia are common. Grade 1-2 toxicities should be taken into consideration, as they contribute to the deterioration of quality of life in older people.

- Erlotinib (150 mg/day) [36,42,45,58,61-65,68,69,72,73,76]:

Hematological toxicities are rare in older subjects (comparable to younger subjects; $1 \%$ to $2 \%$ grade $3-4$ ). They are essentially grade $1-2$ and vary considerably between studies. The most common grade 3-4 non-hematological toxicities with erlotinib in older patients are diarrhea ( $3 \%$ to $17 \%)$ and skin rashes ( $4 \%$ to $14 \%)$. These proportions are higher than in the general population. Grade 1-2 toxicities are mainly diarrhea, anorexia, and cutaneo-mucous signs.

\section{- Gefitinib (250 mg/day) [29-36,44,58,59,67]:}

Anemia is the primary hematological toxicity retained with gefitinib; the incidence varies depending on the studies (3\% to $13 \%$ for grades 3-4). The most common grade 3-4 toxicities in older patients treated with gefitinib (involving nearly $15 \%$ of patients) were an increase in AST / ALAT ( $7 \%$ to $50 \%$ of cases), anorexia ( $5 \%$ to $20 \%$ of cases), diarrhea ( $1 \%$ to $17 \%$ of cases), and skin rash ( $2 \%$ to $16 \%$ of cases). These proportions are higher than in the general population, particularly the increase in AST/ALAT and anorexia. Likewise, the incidence of interstitial lung disease was higher in older patients than in the general population. Regarding grade 1-2 toxicities, digestive, hepatic (increase in AST/ALAT, bilirubin, and PAL), and cutaneo-mucous toxicities were observed in over half of patients. 
Table 4. Prevalence of hematological and biological toxicities according to targeted therapies in trials, cohorts, or trial subgroup post-hoc analysis.

\begin{tabular}{|c|c|c|c|c|c|c|c|c|c|}
\hline Molecules & Afatinib & Gefitinib & Osimertinib & Crizotinib & Ceritinib & Alectinib & Erlotinib & $\begin{array}{l}\text { Combination } \\
\text { of TKI }\end{array}$ & $\begin{array}{l}\text { Combination of TKI and } \\
\text { Chemotherapy }\end{array}$ \\
\hline $\begin{array}{l}\text { Publications } \\
\end{array}$ & $\begin{array}{l}\text { Tanaka } 2018 \text { [26], Imai } 2018 \\
\text { [27], Wu 2018 [44], Corre } \\
2018 \text { [36], Minegishi } 2021 \text { [28] }\end{array}$ & 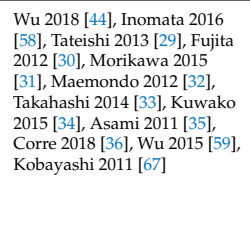 & $\begin{array}{l}\text { Furuta } 2018 \text { [37], Nakao } 2020 \\
\text { [38], Nakao 2019 [60], Auliac } \\
2019 \text { [39], Kato 2019 [40] }\end{array}$ & Bedas 2019 [55] & Bedas 2019 [5] & Bedas 2019 [55] & 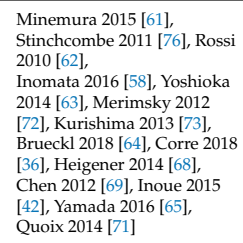 & Gridelli 2011 [70] & $\begin{array}{l}\text { Gridelli } 2011 \text { [70], Stinchcombe } \\
\text { 2011 [76], } \\
\text { Aoshima 2020 [66], } \\
\text { Tam } 2013 \text { [74] }\end{array}$ \\
\hline $\begin{array}{l}\text { Anemia }(\%) \\
\text { Grade } 1-2 \\
\text { Grade } 3-4\end{array}$ & ${ }_{2}^{4-60}$ & $\begin{array}{l}6-50 \\
3-13\end{array}$ & ${ }_{6-43}^{28-75}$ & & & & $6-80$ & 3 & $\begin{array}{l}3-12 \\
8\end{array}$ \\
\hline $\begin{array}{l}\text { Grade } 1-2 \\
\text { Grade } 3-4\end{array}$ & $\begin{array}{l}3-17 \\
1-2\end{array}$ & $1-3$ & $\begin{array}{l}39 \\
3-6\end{array}$ & & & & $\begin{array}{l}3-10 \\
1-2\end{array}$ & & $\begin{array}{l}19 \\
2-3\end{array}$ \\
\hline $\begin{array}{l}\text { Tromonocy yopenia (\%) } \\
\text { Grade } 1-2 \\
\text { Grade }-4\end{array}$ & ${ }_{2}^{21}$ & $1-10$ & $3^{56-58}$ & & & & ${ }_{2}^{17.5}$ & 3 & ${ }_{4-10}^{3}$ \\
\hline $\begin{array}{l}\text { AST/ALT elevation (\%) } \\
\text { Grade } 1-2 \\
\text { Grade 3-4 } \\
\text { Biliubinin elevation (\%) }\end{array}$ & $\begin{array}{l}5-33 \\
5\end{array}$ & $\begin{array}{l}10-60 \\
7-50\end{array}$ & $\begin{array}{l}22-36 \\
6\end{array}$ & 16 & 20 & 22 & $\begin{array}{l}8-37.5 \\
1-6\end{array}$ & 6 & $\begin{array}{l}6-20 \\
2\end{array}$ \\
\hline $\begin{array}{l}\text { Bilirubine elevation (\%) } \\
\text { Grade } 1-2-2 \\
\text { Grade 3-4 } \\
\text { AP levation (\%) }\end{array}$ & 3 & $3^{10-13}$ & 8 & & & & 40 & 6 & \\
\hline $\begin{array}{l}\text { Grade 1-2 } \\
\text { Grade 3-4 } \\
\text { Creatinine elevation } \%\end{array}$ & & 27 & $\begin{array}{l}25-34 \\
6\end{array}$ & & & & & & \\
\hline $\begin{array}{l}\text { Grade } 5 \\
\text { Hypoalbuminemia }(\%)\end{array}$ & & & & & & & 1 & & 2 \\
\hline $\begin{array}{l}\text { Grade 1-2 } \\
\text { Grade 3-4 } \\
\text { Anylas-lipase elevation (\%) } \\
\text { Grade } 1-2\end{array}$ & & 41 & $\begin{array}{l}69-75 \\
3\end{array}$ & & & & & & \\
\hline $\begin{array}{l}\text { Grade } 3-2 \\
\text { Grade } 3-4 \\
\text { Hyperkalemia }\end{array}$ & 3 & & & & & & & 3 & \\
\hline Grade 1-2 $(\%)$ & 23 & & & & & & & & \\
\hline
\end{tabular}

AST = aspartate aminotransferase; ALT = alanine aminotransferase; AP = alkaline phosphatase; TKI: Tyrosine kinase inhibitors. For each treatment, when multiple studies report results given treatment, the percentage observed in the study is reported according to the type of toxicity and its grade. 
Table 5. Prevalence of non-hematological and non-biological toxicities according to targeted therapies in trials, cohorts, or trial subgroup post-hoc analysis.

\begin{tabular}{|c|c|c|c|c|c|c|c|c|c|}
\hline Molecules & Afatinib & Gefitinib & Osimertinib & Crizotinib & Ceritinib & Alectinib & Erlotinib & $\begin{array}{l}\text { Combination } \\
\text { of TKI }\end{array}$ & $\begin{array}{l}\text { Combination of TKI } \\
\text { and Chemotherapy }\end{array}$ \\
\hline Publications & $\begin{array}{l}\text { Tanaka } 2018 \text { [26], Imai } \\
2018 \text { [27], Wu } 2018 \text { [44], } \\
\text { Corre 2018 [36], } \\
\text { Minegishi 2021 [28] }\end{array}$ & $\begin{array}{l}\text { Wu } 2018 \text { [44], } \\
\text { Inomata 2016 [58], } \\
\text { Tateishi } 2013 \text { [29], } \\
\text { Fujita } 2012 \text { [30], } \\
\text { Morikawa 2015 [31], } \\
\text { Maemondo 2012 } \\
\text { [32], Takahashi 2014 } \\
\text { [33], Kuwako 2015 } \\
\text { [34], Asami 2011 [35], } \\
\text { Corre 2018 [36], Wu } \\
2015 \text { [59], Kobayashi } \\
2011 \text { [67] }\end{array}$ & $\begin{array}{l}\text { Furuta } 2018 \text { [37], } \\
\text { Nakao } 2020 \text { [38], } \\
\text { Nakao } 2019 \text { [60], } \\
\text { Auliac } 2019 \text { [39], } \\
\text { Kato } 2019 \text { [40] }\end{array}$ & Bedas 2019 [55] & Bedas 2019 [55] & Bedas 2019 [55] & $\begin{array}{l}\text { Minemura } 2015 \text { [61], } \\
\text { Stinchcombe 2011 [76], } \\
\text { Rossi } 2010 \text { [62], } \\
\text { Inomata } 2016 \text { [58], } \\
\text { Yoshioka } 2014 \text { [63], } \\
\text { Merimsky } 2012 \text { [72], } \\
\text { Kurishima } 2013 \text { [73], } \\
\text { Brueckl } 2018 \text { [64], } \\
\text { Corre } 2018 \text { [36], } \\
\text { Heigener 2014 [68], } \\
\text { Chen 2012 [69], Inoue } \\
\text { 2015 [42], Yamada 2016 } \\
\text { [65], Quoix 2014 [71] }\end{array}$ & Gridelli 2011 [70] & $\begin{array}{l}\text { Gridelli } 2011 \text { [70], } \\
\text { Stinchcombe 2011 } \\
\text { [76], Aoshima 2020 } \\
\text { [66], Tam } 2013 \text { [74] }\end{array}$ \\
\hline \multicolumn{10}{|l|}{ Nausea (\%) } \\
\hline Grade 1-2 & $8-50$ & 2-19 & & 42 & 60 & 22 & 2 & 6 & $16-24$ \\
\hline $\begin{array}{l}\text { Grade 3-4 } \\
\text { Vomiting }(0)\end{array}$ & 3-17 & $2-3$ & & 5 & 20 & & 1 & & 16 \\
\hline Grade 1-2 & 5-50 & $1-23$ & & & & & $1-7.5$ & 6 & \\
\hline Grade 3-4 & $2-3$ & 5 & & & & & 1 & & \\
\hline \multicolumn{10}{|l|}{ Anorexia (\%) } \\
\hline $\begin{array}{l}\text { Grade 1-2 } \\
\text { Grade 3-4 }\end{array}$ & $17-33$ & $13-50$ & $28-31$ & & & & $12.5-50$ & 14 & 3 \\
\hline \multirow{2}{*}{\multicolumn{10}{|c|}{ Dysgeusia (\%) }} \\
\hline $\begin{array}{l}\text { Gysgeusia } 1 \text { (\%) } \\
\text { Grade }\end{array}$ & & & & & & & & & \\
\hline \multicolumn{10}{|l|}{$\begin{array}{l}\text { Grade } 1-2 \\
\text { Grade } 3-4\end{array}$} \\
\hline \multicolumn{10}{|l|}{ Asthenia/fatigue (\%) } \\
\hline $\begin{array}{l}\text { All grades } \\
\text { Grade 1-2 }\end{array}$ & $13-67$ & $6-40$ & $28-31$ & 32 & 40 & 44 & $2-42.5$ & 28 & $19-12$ \\
\hline Grade 3-4 & $1-33$ & 3 & $8-9$ & 5 & & & $2-5$ & 14 & $13-10$ \\
\hline $\begin{array}{l}\text { Diarrhea (\%) } \\
\text { All grades }\end{array}$ & & & & & & & 30 & & \\
\hline Grade 1-2 & $67-100$ & $6-52$ & $22-39$ & 32 & 60 & & $12.5-80$ & 38 & 9-32 \\
\hline Grade 3-4 & $8-33$ & $1-17$ & 2.8 & 10 & & & $3-17$ & 17 & $3-6$ \\
\hline $\begin{array}{l}\text { Grade } 5 \\
\text { Skin rash (\%) }\end{array}$ & & & & & & \\
\hline $\begin{array}{l}\text { Skin rash }(\%) \\
\text { All grades }\end{array}$ & & & & & & & 69 & & \\
\hline Grade 1-2 & $33-74$ & $31-90$ & $22-36$ & & & & 3-95 & 35 & $26-30-60$ \\
\hline Grade 3-4 & $5-33$ & $2-16$ & & & & & $4-14$ & 13 & $4-6-16$ \\
\hline \multicolumn{9}{|l|}{ Acne (\%) } & \\
\hline All grades & & & & & & & & & 47 \\
\hline Grade 1-2 & & & & & & & 45 & & \\
\hline \multirow{2}{*}{\multicolumn{10}{|c|}{$\begin{array}{l}\text { Grade } 3-4 \text { (\%) } \\
\text { Paronychia (\%) }\end{array}$}} \\
\hline & & & & & & & & & \\
\hline Grade $1-2$ & $26-50$ & $19-30$ & 33 & & & & $6-37.5$ & 3 & 3-36 \\
\hline Grade $3-4$ & $5-28$ & $4-5$ & $17-42$ & & & & & & \\
\hline $\begin{array}{l}\text { Mucositis-stomatitis (\%) } \\
\text { Grade 1-2 }\end{array}$ & $31-60$ & $1-24$ & $17-22$ & & & & $6-125-28$ & & $16-19$ \\
\hline Grade 3-4 & $3-50$ & $3-8$ & & & & & & & \\
\hline
\end{tabular}


Table 5. Cont.

\begin{tabular}{|c|c|c|c|c|c|c|c|c|c|}
\hline Molecules & Afatinib & Gefitinib & Osimertinib & Crizotinib & Ceritinib & Alectinib & Erlotinib & $\begin{array}{l}\text { Combination } \\
\text { of TKI }\end{array}$ & $\begin{array}{l}\text { Combination of TKI } \\
\text { and Chemotherapy }\end{array}$ \\
\hline \multicolumn{10}{|l|}{ Dry skin $(\%)$} \\
\hline Grade 1-2 & $9-38$ & $8-65$ & & & & & $6-59$ & & \\
\hline Grade 3-4 & & & & & & & $3-5$ & & \\
\hline \multicolumn{10}{|l|}{ Pruritus (\%) } \\
\hline Grade 1-2 & $14-26$ & $6-24$ & 22 & & & & 62.5 & & 3 \\
\hline \multirow{2}{*}{\multicolumn{10}{|c|}{ Urticaria (\%) }} \\
\hline & & & & & & & & & \\
\hline \multirow{2}{*}{\multicolumn{10}{|c|}{$\begin{array}{l}\text { Grade 1-2 } \\
\text { Grade 3-4 }\end{array}$}} \\
\hline & & & & & & & & & \\
\hline \multicolumn{10}{|l|}{ Edema (\%) } \\
\hline Grade $1-2$ & 10.5 & & & 37 & & 33 & & & \\
\hline \multicolumn{9}{|l|}{ Infection (\%) } & \\
\hline Grade 1-2 & $3-17$ & & & & & & 1 & & \\
\hline \multirow{2}{*}{\multicolumn{10}{|c|}{$\begin{array}{l}\text { Interstitial lung disease }(\%) \\
\text { Inter }\end{array}$}} \\
\hline & & & & & & & & & \\
\hline Grade 1-2 & 8 & $1-6$ & 3 & 5 & & & 1 & & \\
\hline Grade 3-4 & $5-10$ & $2-4$ & $6-9$ & & & & $1-6$ & & 2 \\
\hline \multicolumn{10}{|l|}{ Grade 5} \\
\hline Constipation (\%) & & & & & & & & & \\
\hline Grade 1-2 & $3-4$ & 6.5 & & 10 & & & & & \\
\hline \multicolumn{10}{|l|}{ Grade $3-4$} \\
\hline \multicolumn{10}{|l|}{ Dehydration (\%) } \\
\hline \multicolumn{10}{|l|}{ Grade 1-2 } \\
\hline Grade 1-2 & & $6-10$ & & & & & 19 & 3 & 6 \\
\hline \multirow{2}{*}{\multicolumn{10}{|c|}{$\begin{array}{l}\text { Grade 3-4 } \\
\text { Pigmentation (\%) }\end{array}$}} \\
\hline & & & & & & & & & \\
\hline \multirow{2}{*}{\multicolumn{10}{|c|}{$\begin{array}{l}\text { Grade } 1-2 \\
\text { Faintness (\%) }\end{array}$}} \\
\hline & & & & & & & & & \\
\hline Grade 1-2 & & 12 & & & & & 6 & & \\
\hline \multirow{2}{*}{\multicolumn{10}{|c|}{$\begin{array}{l}\text { Grade } 3-4 \\
\text { Ventricular dysfunction (\%) }\end{array}$}} \\
\hline & & & & & & & & & \\
\hline \multirow{2}{*}{\multicolumn{10}{|c|}{$\begin{array}{l}\text { Grade 3-4 } \\
\text { Prolonged QT interval (\%) }\end{array}$}} \\
\hline & & & & & & & & & \\
\hline Grade 1-2 & & & & 10 & & & & & \\
\hline \multirow{2}{*}{\multicolumn{10}{|c|}{ Hand-foot syndrome (\%) }} \\
\hline & & & & & & & & & \\
\hline Grade 1-2 & & & & & & & 27.5 & 21 & 20 \\
\hline \multirow{2}{*}{\multicolumn{10}{|c|}{$\begin{array}{l}\text { Grade } 3-4 \\
\text { Delirium }(\%)\end{array}$}} \\
\hline & & & & & & & & & \\
\hline Grade 3-4 & & & 3 & & & & & & \\
\hline \multicolumn{10}{|l|}{ Dyspnea (\%) } \\
\hline All grades & & & & & & & 17.5 & & \\
\hline Grade 3-4 & & & 3 & & & & & & 6 \\
\hline
\end{tabular}


Table 5. Cont.

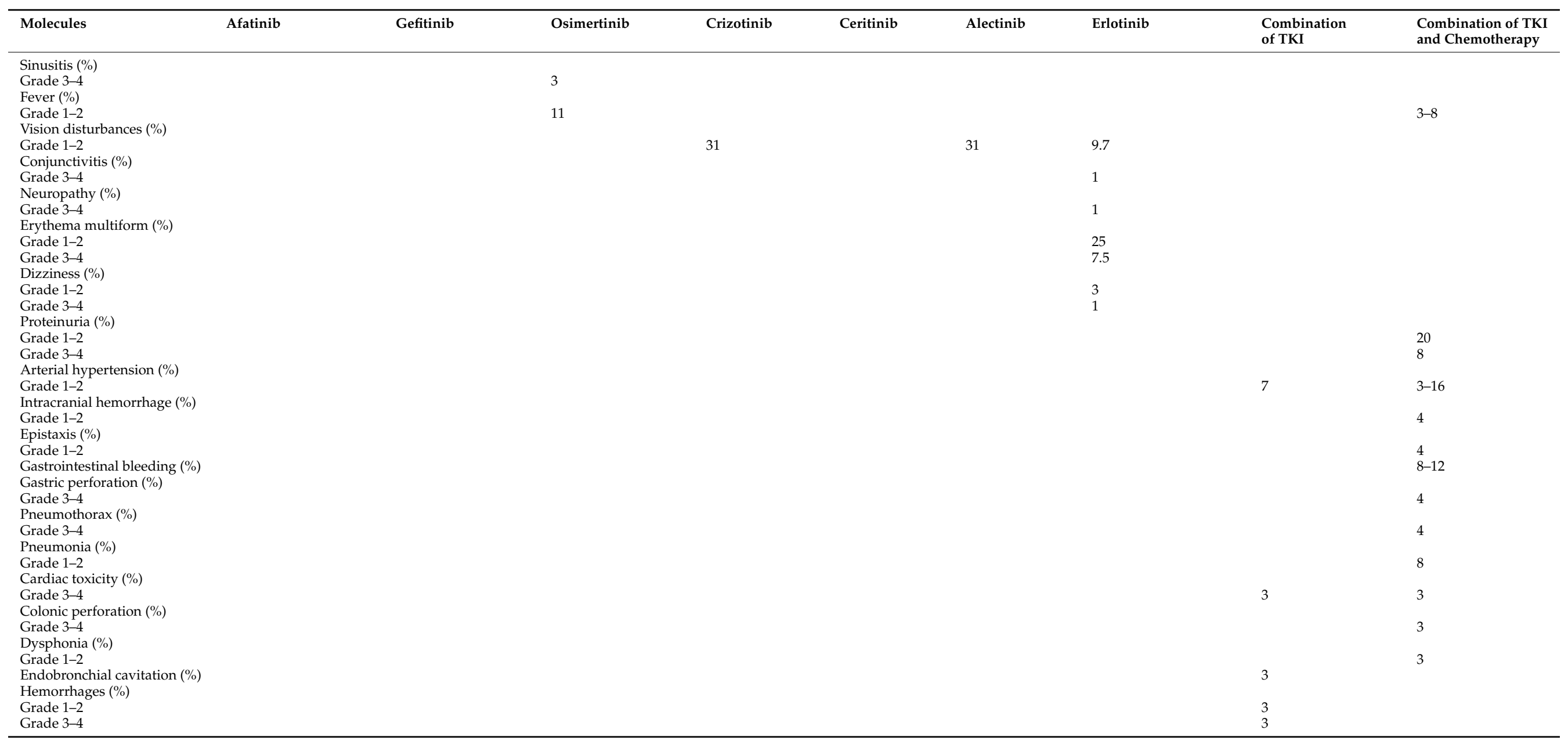

TKI: Tyrosine kinase inhibitors. For each treatment, when multiple studies report results by type of toxicity and grade, the minimum percentage observed and the maximum percentage observed in these studies are reported in the table. When there is only one study for a given treatment, the percentage observed in the study is reported according to the type of toxicity and its grade. 


\section{- $\quad$ Osimertinib (80 mg/day) [37-40,60]:}

In older patients on osimertinib, there is a hematological risk of all grades and, in particular, a grade 3-4 risk of anemia (up to $43 \%$ ). The most common grade 3-4 nonhematological toxicities in older subjects treated with osimertinib are anorexia (11\%) and paronychia (up to $42 \%$ ). These proportions are higher than in the general population. Likewise, the proportion developing interstitial lung disease is higher in older patients ( $5 \%$ to $10 \%$ ) compared to the general population. The risk of QT prolongation should be taken into consideration, even though only one study has highlighted this risk, and an ECG should be systematically conducted before initiating osimertinib. Concerning grade 1-2 toxicities, digestive and cutaneo-mucous toxicities are common, as well as an increase in AST/ALAT and hypoalbuminemia.

- $\quad$ Combination of targeted therapy and chemotherapy $[66,70,74,76]$ :

Combination of erlotinib (100 mg/day) + gemcitabine: Grade 3-4 cytopenia was observed in less than $8 \%$ of cases in the studies. Regarding non-hematological toxicities, primarily $47 \%$ of acne of all grades was reported.

Combination of erlotinib or gefitinib + chemotherapy (cisplatin, carboplatin, gemcitabine, paclitaxel, docetaxel, pemetrexed, vinorelbine, or etoposide). Regarding the toxicity data of erlotinib and gefitinib combined, almost $30 \%$ grade $1-2$ skin rashes and $4 \%$ grade $3-4$, and $2 \%$ grade 3-4 lung involvement, were reported. There is no toxicity more specific to older subjects for a protocol combining chemotherapy and anti-EGFR TKI.

Combination of erlotinib (150 mg/day) + bevacizumab: There is no toxicity more specific to older subjects for a protocol combining an anti-angiogenic and an anti-EGFR TKI. Particular attention must be paid to cytopenia, hemorrhagic events, hypertension, and proteinuria, but this combination is of no interest in practice.

Combination of sorafenib ( $800 \mathrm{mg} /$ day $)+$ gemcitabine: There is no toxicity specific to older subjects but this combination is of no interest in practice.

- $\quad$ Combination of erlotinib (150 mg/day) + sorafenib (800 mg/day):

There is no toxicity data specific to older subjects but this combination is of no interest in practice.

\subsubsection{ALK Tyrosine Kinase Inhibitors}

- $\quad$ Alectinib (600 mg twice/day) [55]:

The tolerance profile of alectinib seems comparable to that of the general population, except for vision disorders (grades 1-2; 31\% of cases), which are more common in older patients. Hematological toxicity was not reported.

\section{- $\quad$ Ceritinib (450 mg/day) [55]:}

The tolerance profile of ceritinib seems comparable to that of the general population, except for an increase in creatinine, more common in older patients ( $20 \%$ to $40 \%$ of cases). Grade 3-4 non-hematological toxicities included nausea in $20 \%$ of cases, and oedema in $8 \%$ of cases.

- Crizotinib (250 mg twice/day) [55]:

The tolerance profile of crizotinib (digestive adverse events, such as grade 3-4 nausea in $5 \%$ of cases and grade $3-4$ diarrhea in $10 \%$ of cases, and grade $1-2$ pulmonary adverse events in $5 \%$ of cases) seems comparable to that of the general population, except for QT prolongation (grade 1-2 in 10\% of cases), which is more common in older patients.

\subsection{Feasibility}

Tables 6 and 7. 
Table 6. Targeted therapy feasibility results in older patients in non-randomized trials.

\begin{tabular}{|c|c|c|c|c|c|c|c|c|}
\hline Molecules & Afatinib & Gefitinib & Osimertinib & Crizotinib & Ceritinib & Alectinib & Erlotinib & $\begin{array}{l}\text { Combination of } \\
\text { TKI and } \\
\text { Chemotherapy }\end{array}$ \\
\hline Publications & $\begin{array}{l}\text { Tanaka } 2018 \text { [26], Imai } \\
2018 \text { [27], Corre 2018 [36], } \\
\text { Minegishi } 2021 \text { [28] }\end{array}$ & $\begin{array}{l}\text { Douillard } 2014 \text { [52], } \\
\text { Inomata } 2016 \text { [58], } \\
\text { Tateishi } 2013 \text { [29], Fujita } \\
2012 \text { [30], Morikawa } 2015 \\
\text { [31], Maemondo 2012 } \\
\text { [32], Takahashi 2014 [33], } \\
\text { Kuwako 2015 [34], } \\
\text { Asami 2011 [35], Corre } \\
\text { 2018 [36], Wu 2015 [59], } \\
\text { Kobayashi } 2011 \text { [67] }\end{array}$ & $\begin{array}{l}\text { Furuta } 2018 \text { [37], } \\
\text { Nakao } 2020 \text { [38], } \\
\text { Nakao } 2019 \text { [60], } \\
\text { Auliac } 2019 \text { [39], } \\
\text { Kato } 2019 \text { [40] }\end{array}$ & Bedas 2019 [55] & Bedas 2019 [55] & Bedas 2019 [55] & $\begin{array}{l}\text { Minemura } 2015 \text { [61], } \\
\text { Stinchcombe } 2011 \text { [76], } \\
\text { Rossi 2010 [62], } \\
\text { Yoshioka 2014 [63], } \\
\text { Merimsky } 2012 \text { [72], } \\
\text { Kurishima } 2013 \text { [73], } \\
\text { Brueckl 2018 [64], Corre } \\
2018 \text { [36], Heigener 2014 } \\
\text { [68], Chen 2012 [69], Inoue } \\
2015 \text { [42], Yamada 2016 [65] }\end{array}$ & $\begin{array}{l}\text { Aoshima } 2020 \text { [66], } \\
\text { Tam } 2013 \text { [74] }\end{array}$ \\
\hline $\begin{array}{l}\text { Median duration of } \\
\text { treatment (months) }\end{array}$ & $4.0(1-69)$ & $1.6-8.0$ & $15.0 \pm 9$ & 4.2 & 5.8 & 5.0 & $\begin{array}{l}1-39 \\
1-9 \\
1.7-6.2\end{array}$ & 10.4 \\
\hline Dose reduction (\%) & $47.5-89$ & $20-45$ & $19-39$ & 21 & 60 & 44 & $7-56$ & 64 \\
\hline $\begin{array}{l}\text { Treatment } \\
\text { discontinuation due to } \\
\text { toxicity }(\%)\end{array}$ & $5-21$ & $3-52$ & $9-28$ & 21 & 60 & & $4-45$ & \\
\hline $\begin{array}{l}\text { Dose reduction due to } \\
\text { toxicity }(\%)\end{array}$ & & 17 & $9-28$ & & & & $7-56$ & 64 \\
\hline
\end{tabular}

TKI: Tyrosine kinase inhibitors. For each treatment, when several studies express results as medians with intervals, the minimum and maximum medians observed are reported in the table. When there is only one study for a given treatment, the median with its interval is reported in the table. For each treatment, when multiple studies report results by dose reduction and treatment discontinuation, the minimum percentage observed and the maximum percentage observed in these studies are reported in the table. When there is only one study for a given treatment, the percentage observed in the study is reported according to dose reduction or treatment discontinuation. 
Table 7. Targeted therapy feasibility results in older patients in randomized trials.

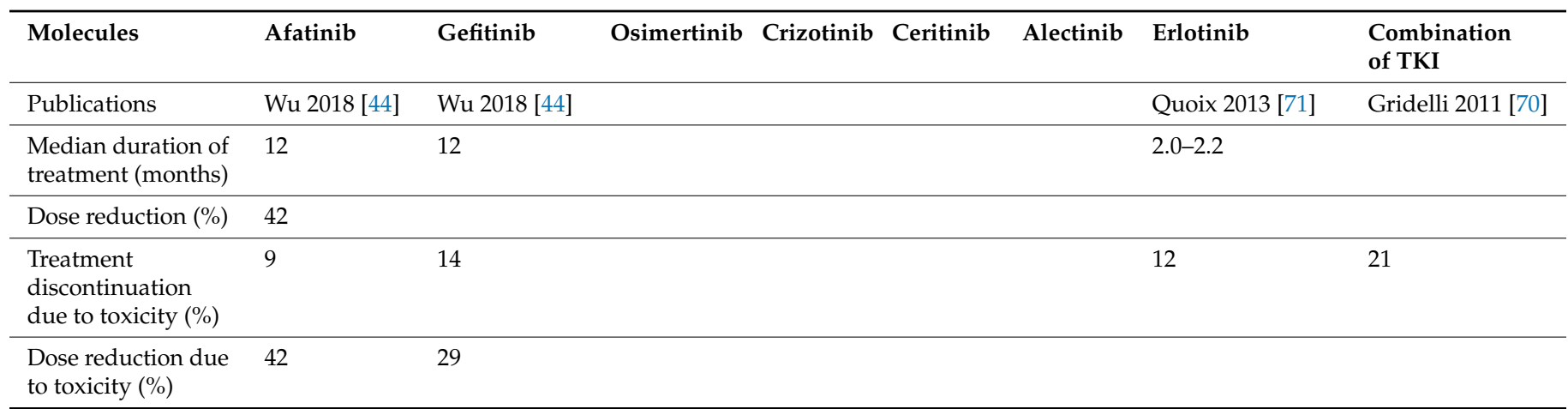

TKI: Tyrosine kinase inhibitors. For each treatment, when several studies express results as medians with intervals, the minimum and maximum medians observed are reported in the table. When there is only one study for a given treatment, the median with its interval is reported in the table. For each treatment, when multiple studies report results by dose reduction and treatment discontinuation, the minimum percentage observed and the maximum percentage observed in these studies are reported in the table. When there is only one study for a given treatment, the percentage observed in the study is reported according to dose reduction or treatment discontinuation.

\subsubsection{EGFR Tyrosine Kinase Inhibitors}

- $\quad$ Afatinib (40 mg/day) [26-28,36,77]:

Full-dose treatment in older subjects is not very feasible, and afatinib requires dose adjustments in $42 \%$ to $89 \%$ of cases. Changes in dose are primarily due to toxicities.

- $\quad$ Erlotinib (150 mg/day) [36,42,45,61-65,68,69,72,73,76]:

Full-dose treatment with erlotinib in older subjects is feasible and requires dose adjustments in $7 \%$ to $56 \%$ of cases.

- Gefitinib (250 mg/day) [29-36,44,52,58,59,67]:

Full-dose treatment with gefitinib in older subjects is feasible in most cases and requires dose adjustments in $17 \%$ to $52 \%$ of cases. In practice, there is not one single dosage. A trial will be necessary to see if intermittent treatment is required if the dose needs adjusting.

- Osimertinib (80 mg/day) [37-40,60]:

Full-dose treatment with osimertinib in older subjects is feasible in most cases and requires dose adjustments in $9 \%$ to $28 \%$ of cases.

- Erlotinib or Gefitinib + Chemotherapy [66]:

Full-dose treatment with gefitinib or erlotinib + chemotherapy in older subjects is not very feasible and requires dose adjustments in $64 \%$ of cases.

- Combination of Targeted Therapy (Sorafenib + Erlotinib) [70]:

There is little data on the feasibility of erlotinib + sorafenib and no indication in practice.

\subsubsection{ALK Tyrosine Kinase Inhibitors}

- Alectinib (600 mg twice/day) [55]:

Little data is available regarding the feasibility of alectinib in older subjects. Nevertheless, a trial reports a $44 \%$ reduction in dose intensity.

- Ceritinib (450 mg/day) [55]:

It is difficult to any draw conclusions regarding the feasibility of ceritinib as there are so few trials including older subjects. Treatment discontinuation due to toxicity in $60 \%$ of cases was observed; thus, caution is required in older subjects.

- Crizotinib (250 mg twice/day) [55]:

It is difficult to draw any conclusions regarding the feasibility of crizotinib as there are so few trials including older subjects. 


\subsection{Quality of Life}

Only four articles $[31,33,69,76]$ included an analysis of quality of life. One article comparing erlotinib alone or combined with chemotherapy or chemotherapy alone showed no significant difference between the three arms regarding quality of life. Another article comparing gefitinib and chemotherapy (carboplatin/paclitaxel) showed no difference between the two treatments in terms of pain, dyspnea, anxiety, and function between patients under and over 70 years. In Takahashi et al. [33], cough and breathlessness improved significantly in 20 older patients treated with gefitinib after 4 weeks of treatment. In Chen et al. [69], in a study comparing erlotinib and vinorelbine-type chemotherapy, there was no significant difference between erlotinib and chemotherapy, except for physical well-being, which was better in the erlotinib group. A priori, there was no change in quality of life of older patients on TKI compared to those undergoing chemotherapy (Table 8).

Table 8. Geriatric assessment and quality of life results in older patients in randomized and nonrandomized trials.

\begin{tabular}{|c|c|c|c|c|c|}
\hline Publication & Treatment & $\begin{array}{l}\text { Median Age } \\
\text { (Years) }\end{array}$ & $\begin{array}{l}\text { Comorbidities-Charlson } \\
\text { Scale (CCI) or Frailty } \\
\text { Scales }(\%)\end{array}$ & Quality of Life & CGA \\
\hline Aoshima 2020 [66] & $\begin{array}{l}\text { Erlotinib } 150 \mathrm{mg} / \text { day + } \\
\text { bevacizumab }\end{array}$ & 80 & $\begin{array}{l}C C I=1: 36 \%, C C I=2: 4 \% \\
C C I \geq 3: 8 \%\end{array}$ & & \\
\hline Stinchcombe 2011 [76] & $\begin{array}{l}\text { Erlotinib } 100 \mathrm{mg} / \text { day }+ \\
\text { chemotherapy or erlotinib } \\
\text { alone }(150 \mathrm{mg} / \text { day }) \text { or } \\
\text { chemotherapy alone }\end{array}$ & 76 & CIRS-G frailty scale & $\begin{array}{l}\text { No differences in quality } \\
\text { of life }\end{array}$ & \\
\hline Morikawa 2015 [31] & $\begin{array}{l}\text { Gefitinib } 250 \mathrm{mg} / \text { day or } \\
\text { carboplatin/paclitaxel }\end{array}$ & 75 & & $\begin{array}{l}\text { No differences in the quality } \\
\text { of life domains of pain and } \\
\text { dyspnea, anxiety, and daily } \\
\text { functioning between }<70 \\
\text { and }>70 \text { years groups }\end{array}$ & \\
\hline Takahashi 2014 [33] & Gefitinib $250 \mathrm{mg} /$ day & 79.5 & & $\begin{array}{l}\text { Shortness of breath and } \\
\text { cough improved } \\
\text { significantly after } 4 \text { weeks } \\
\text { of treatment }\end{array}$ & \\
\hline Miyamoto 2020 [41] & Erlotinib $50 \mathrm{mg} /$ day & 80 & $\begin{array}{l}\mathrm{CCI} \geq 6 \text { was the cut off } \\
\text { for frailty }\end{array}$ & & \\
\hline Corre 2018 [36] & $\begin{array}{l}\text { Gefitinib or erlotinib } \\
\text { or afatinib }\end{array}$ & 83.9 & & & $\begin{array}{l}\text { CGA was performed } \\
\text { for } 35 \% \text { of patients }\end{array}$ \\
\hline Inoue 2015 [42] & Erlotinib 150 mg/day & 80 & $\begin{array}{l}\text { CCI 1-2: } 44 \% \\
\text { CCI } \geq 3: 6 \%\end{array}$ & & \\
\hline Chen 2012 [69] & $\begin{array}{l}\text { Erlotinib } 150 \mathrm{mg} / \text { day } \\
\text { or vinorelbine }\end{array}$ & 77 & & $\begin{array}{l}\text { Patients in the erlotinib } \\
\text { arm had significantly } \\
\text { better physical well-being } \\
\text { than patients in the } \\
\text { vinorelbine arm }\end{array}$ & \\
\hline Quoix 2013 [71] & $\begin{array}{l}\text { Erlotinib } 150 \mathrm{mg} / \text { day } \\
\text { (second line) }\end{array}$ & & $\mathrm{CCI} \leq 2: 68 \%$ & & $\begin{array}{l}\text { MMSE < 24: } 52 \% \\
\text { ADL < 6: } 49 \% \\
\text { BMI < 21: } 61.5 \%\end{array}$ \\
\hline Tam 2013 [74] & $\begin{array}{l}\text { Erlotinib or gefitinib (first } \\
\text { or second line) }\end{array}$ & 73 & $\mathrm{CCI}=1: 18 \%, \mathrm{CCI}=2: 9 \%$ & & \\
\hline
\end{tabular}

ADL: activities of daily living; CIRS-G: cumulative illness rating scale; CCI: Charlson scale; CGA: comprehensive geriatric assessment; BMI: body mass index; MMSE: mini mental state examination.

\subsection{Geriatric Data}

In the studies included for efficacy, 20 articles included patients with an ECOG-PS $\geq 2$ of which the extremes varied from $2 \%$ to $42 \%$. The studies not including ECOG-PS $\geq 2$ patients were randomized studies (subgroups of older subjects). In Kato et al. [40], according to the multivariate analysis, age and ECOG were two independent factors of treatment efficacy with osimertinib. In Brueckl et al. [64], the OS curve for 385 older patients treated with erlotinib was not significantly different according to the age groups and the ECOG-PS. Only 7 studies $[36,41,42,66,71,74,76]$ included geriatric or frailty data in the descriptive analyses. The Charlson Comorbidity Index (CCI) was the most commonly used in the Comprehensive Geriatric Assessment (CGA), with few patients having comorbidities in most of these 
studies, as the percentage of CCI $\geq 3$ varied from $6 \%$ to $8 \%$. In Stinchcombe et al. [76], the CIRS-G frailty scale was used, and the median severity index was lower in the erlotinib group (compared with chemotherapy alone or the erlotinib + chemotherapy arm) but was not significantly different. Only two studies conducted a CGA [36,71]; one study [71] included patients with suspected cognitive disorders in $52 \%$ of cases (Mini Mental State Evaluation $\leq 23$ ), loss of autonomy with activities of daily living (ADL) in $49 \%$ of cases, and a body mass index (BMI) indicating probable denutrition in $61.5 \%$ of cases. According to the logistic regression, factors associated with erlotinib treatment (second-line) in this article were PS between 0 and 1, stage IV, and an ADL index of 6. Multivariate analysis identified weight loss $\leq 5 \%$ as being associated with better OS. The other study [36] showed that 39\% of patients were taking $\geq 6$ drugs per day. In Miyamoto et al. [41], an ECOG-PS $\geq 2$ was associated with a shorter PFS and OS, and a CCI $\geq 2$ was associated with a shorter PFS. So, there is currently very little clinical data available to determine the geriatric profile of older patients likely to receive targeted therapy. Most of the studies included robust older patients with good PS and very few comorbidities (Table 8).

\section{Discussions}

\subsection{For Which Older Patients with NSCLC Can We Propose the Following TKI? \\ 4.1.1. EGFR Tyrosine Kinase Inhibitors}

Osimertinib, $80 \mathrm{mg} /$ day, is used as a first-line treatment in older patients with the EGFR mutation (exon 19 deletion or L858R mutation). Osimertinib, $80 \mathrm{mg} /$ day, is used as a second-line treatment in the case of a T790M resistance mutation in older patients pretreated with first and second generation TKI (grade C).

Full-dose treatment is feasible in older subjects but more intensive hematological monitoring than with younger patients is strongly recommended. Monitoring is recommended with osimertinib (80 mg/day): Clinical monitoring, electrocardiogram (ECG) (QT prolongation), and biological monitoring (blood count, ionogram, creatinine, AST / ALAT (Aspartate aminotransferase/Alanine aminotransferase), and AP (Alcaline phosphatase), bilirubin, albumin) (grade C) must be systematic and regular in older subjects (at least every 15 days for the first three months) (expert agreement). Given the prevalence of grade 1-2 hypoalbuminemia, nutritional status must be monitored in older subjects (at least once/month) (expert agreement).

Concerning afatinib, full-dose treatment in older subjects is not very feasible. A reduction in dose is necessary in most cases (grade $\mathrm{A}$ ).

Clinical and biological monitoring (blood count, ionogram, creatinine, AST / ALAT) (grade B) are necessary with afatinib (40 mg/day) and must be systematic and regular for older subjects (at least every 15 days for the first three months) (expert agreement).

Full-dose treatment with erlotinib is feasible (grade B). Clinical and biological monitoring (blood count, ionogram, creatinine, AST/ALAT) are necessary with erlotinib (150 mg/day) (grade C) and must be systematic and regular for older subjects (at least every 15 days for the first three months) (expert agreement).

Full-dose treatment with gefitinib is feasible (grade C). Clinical and biological monitoring (blood count, ionogram, creatinine, AST/ALAT, AP, bilirubin) are required with gefitinib (250 mg/day) (grade C) and must be systematic and regular for older subjects (at least every 15 days for the first three months) (expert agreement).

\subsubsection{ALK Tyrosine Kinase Inhibitors}

In older patients with an ALK rearrangement, there is very scarce data to enable specific recommendations to be established. The recommendations are the same as for younger patients: Alectinib $600 \mathrm{mg}$ twice/day is given as a first-line treatment, but beware of the risk of dose reduction with alectinib, and also brigatinib $90 \mathrm{mg}$ per day for the first 7 days and then $180 \mathrm{mg}$ per day (grade C). Phase IV data are necessary to draw conclusions regarding the feasibility of this treatment in an older population. Alectinib (600 mg/day) requires clinical (in particular, ophthalmic) and biological monitoring (blood 
count, ionogram, creatinine, AST /ALAT) (grade C) and must be systematic and regular for older subjects (at least every 15 days for the first three months) (expert agreement).

Clinical, ECG, and biological monitoring (blood count, ionogram, creatinine, AST/ALAT) are required with ceritinib ( $450 \mathrm{mg}$ /day) (grade C) and must be systematic and regular for older subjects (at least every 15 days for the first three months) (expert agreement).

Clinical, ECG, and biological monitoring (blood count, ionogram, creatinine, AST/ALAT) are required with crizotinib (250 mg twice/day) (grade C) and must be systematic and regular for older subjects (at least every 15 days for the first three months) (expert agreement).

4.1.3. The ROS Tyrosine Kinase Inhibitor Found in this Systematic Review in Older Subjects: Crizotinib

Regarding ROS1 rearrangements, there is very little data to enable specific recommendations to be issued for older subjects. The recommendations are the same as for younger subjects: Crizotinib $250 \mathrm{mg}$ twice a day is given as a first-line treatment (grade B). Phase IV trials are necessary. Clinical, ECG, and biological monitoring (blood count, ionogram, creatinine, AST/ALAT) are required with crizotinib (250 mg twice/day) (grade B) and must be systematic and regular for older subjects (at least every 15 days for the first three months) (expert agreement).

\subsection{For Which Older Patients with NSCLC Should We Consider Monotherapy (TKI Alone)?}

For the time being, given the data in the literature regarding older subjects treated with TKI, there is no indication to combine TKI with chemotherapy or another systemic treatment. TKI is to be prescribed as monotherapy in this population (expert agreement). Moreover, there is no marketing authorization for combinations of chemotherapy and TKI for NSCLC.

\subsection{For Which Older Patients with NSCLC Can We Consider a Combination of Several TKI?}

Even though TKI combination is not yet approved by the Food and Drugs Administration or the European Medicines Agency (EMA), some studies have already explored the possibility of combination treatment with TKI $[77,78]$. For the time being, given the lack of data in the literature on older subjects treated with TKI, there is no indication to combine several TKI in this population for the moment (expert agreement).

\subsection{General Recommendations for Prescribing TKI for the Treatment of NSCLC in Older Patients}

Regarding the conditions for prescribing TKI in older subjects ( $\geq 70$ years), a CGA can help identify de-nutrition, comorbidities, and an alteration of functional status, which have an impact on overall survival and progression-free survival (grade B), and propose corrective action. So, a CGA must be recommended for older patients with a G8 $\leq 14 / 17$ according to the recommendations [79], but it is also important to assess nutritional status through changes in weight or BMI or MNA (Mini Nutritional Assessment) [80,81], functional status through ADL (Activities of Daily Living) [81,82], and comorbidities using the Charlson index [83] or CIRS-G (Cumulative Illness Rating Scale-Geriatric) [84] before prescribing TKI in older patients with NSCLC (expert agreement).

Targeted therapy does not seem to have a greater impact on quality of life than other systemic treatments but must be monitored regularly (grade B). In view of the literature studied, the work group does not recommend any particular tool to measure quality of life (expert agreement).

\section{Conclusions}

This is the first review in the current literature grouping two learned societies (SPLF/ GOLF and SoFOG) and bringing together experts in pulmonary-oncology and geriatric oncology on the subject of prescribing targeted therapy in older patients with NSCLC. These recommendations are based on 52 articles included from May 2010 to May 2020 and after revision between April 2020 and May 2021. The selection process is documented 
in a PRISMA flow diagram. Regarding EGFR tyrosine kinase inhibitors, first generation molecules, such as erlotinib and gefitinib, can be used at full dose but afatinib, a second generation TKI, is not feasible at full dose in older subjects. Osimertinib (3rd generation TKI) at a dose of $80 \mathrm{mg} /$ day seems to be the best treatment option for older patients with the EGFR mutation (exon 19 deletion or L858R mutation) and as a second-line treatment in the case of a T790M resistance mutation. Hematological monitoring must be reinforced with this treatment. For ALK and ROS1 tyrosine kinase inhibitors, the lack of data prevents specific recommendations being established for older subjects. Given the data in the literature, targeted therapies must not be combined together or with chemotherapy, for the time being. Finally, a geriatric assessment is recommended after conducting a G8-type test to identify frailty (if $\leq 14 / 17$ ), as well as to identify comorbidities that could interfere with the good progress of the treatment, loss of functional status, and alteration of nutritional status. Polypharmacy ( $\geq 5$ drugs) also needs to be investigated to request the help of pharmacists in identifying any interactions between regular medications and the targeted therapy initiated.

Supplementary Materials: The following supporting information can be downloaded at: https: / / www.mdpi.com/article/10.3390/cancers14030769/s1, Figure S1: MeSH terms; Table S1. Table of the recommendations staging (grade A, B or C) translated from [25].

Author Contributions: Conceptualization, L.G., M.G., E.P., S.M.-P. and A.-L.C.; methodology, S.M.-P., M.G., Y.B., M.F. and P.N.; software, M.G. and S.M.-P.; validation, L.G., M.G., E.P., N.G., C.M., R.B., M.W., F.P., R.C., M.C., P.C., Y.B., M.F., P.N., P.W., S.M., S.M.-P. and A.-L.C.; formal analysis, M.G. and S.M.-P.; investigation, L.G., M.G., E.P., N.G., C.M., R.B., M.W., F.P., R.C., M.C., P.C., Y.B., M.F., P.N., P.W., S.M., S.M.-P. and A.-L.C.; writing-original draft preparation, L.G., M.G. and A.-L.C.; writing—review and editing, L.G., M.G., E.P., S.M.-P. and A.-L.C.; visualization, L.G., M.G., E.P., N.G., C.M., R.B., M.W., F.P., R.C., M.C., P.C., Y.B., M.F., P.N., P.W., S.M., S.M.-P. and A.-L.C.; supervision, E.P. and S.M.-P.; project administration, L.G., M.G., E.P., N.G., C.M., R.B., M.W., F.P., R.C., M.C., P.C., Y.B., M.F., P.N., P.W., S.M., S.M.-P. and A.-L.C. All authors have read and agreed to the published version of the manuscript.

Funding: This research received no external funding.

Acknowledgments: We thank the review group: Fabrice Barlesi (French-language Society of Pulmonology (SPLF)/French-language Oncology Group (GOLF)), Claire Falandry (French Society of Geriatric Oncology (SoFOG)), Maxime Frelaut (French Society of Geriatric Oncology (SoFOG)) and Elisabeth Quoix (French-language Society of Pulmonology (SPLF)/French-language Oncology Group (GOLF)). We thank Caroline Lalet and Arthur Cohen (Inserm CIC1401, Institut Bergonié, Clinical Research Plateform for older patients with cancer (PACAN)) for their support building search algorithms. We thank Emilie Nouguerede (Internal Medicine, Geriatrics and Therapeutic Unit, AP-HM, Marseille, France) for their support in the formatting of the manuscript.

Conflicts of Interest: The following authors have relevant financial activities to declare: LG: Abbvie, Bristol Myers Squibb, Boehringer Ingelheim, AstraZeneca, Roche, Novartis, MSD, Pfizer and Takeda; EP: BMS, Leo Pharma, Amgen, Pfizer and Nutricia; NG: Roche, AstraZeneca, Pfizer, Takeda, Bayer, Janssen, Boehringer Ingelheim, Novartis and BMS; RB: Teva, BMS, Sanofi, Hospira, Nutricia, Novartis, Lilly, Pierre-Fabre, Roche, Takeda and Servier. MW: Roche, AstraZeneca, MSD, BMS, Lilly, Amgen and Pfizer; RC: AstraZeneca, BMS, Roche, Boehringer Ingelheim, Takeda and Pfizer; PC: Pfizer; PN: Pfizer, Merck-Serono and Novartis Pharma; ALC: BMS, Nutricia, Ferring and Amgen.

\section{References}

1. Owonikoko, T.K.; Ragin, C.C.; Belani, C.P.; Oton, A.B.; Gooding, W.E.; Taioli, E.; Ramalingam, S.S. Lung cancer in elderly patients: An analysis of the surveillance, epidemiology, and end results database. J. Clin. Oncol. 2007, 25, 5570-5577. [CrossRef] [PubMed]

2. SEER Cancer Statistics Review, 1975-2010-Previous Version-SEER Cancer Statistics Review. Available online: https://seer. cancer.gov/archive/csr/1975_2010/index.html (accessed on 18 December 2021).

3. Ferlay, J.; Colombet, M.; Soerjomataram, I.; Dyba, T.; Randi, G.; Bettio, M.; Gavin, A.; Visser, O.; Bray, F. Cancer incidence and mortality patterns in europe: Estimates for 40 countries and 25 major cancers in 2018. Eur. J. Cancer 2018, 103, 356-387. [CrossRef] [PubMed] 
4. Ruiter, R.; Burggraaf, J.; Rissmann, R. Under-representation of elderly in clinical trials: An analysis of the initial approval documents in the food and drug administration database. Br. J. Clin. Pharmacol. 2019, 85, 838-844. [CrossRef] [PubMed]

5. Mangoni, A.A.; Jackson, S.H.D. Age-related changes in pharmacokinetics and pharmacodynamics: Basic principles and practical applications. Br. J. Clin. Pharmacol. 2004, 57, 6-14. [CrossRef]

6. Giroux Leprieur, E.; Labrune, S.; Giraud, V.; Gendry, T.; Cobarzan, D.; Chinet, T. Delay between the initial symptoms, the diagnosis and the onset of specific treatment in elderly patients with lung cancer. Clin. Lung. Cancer 2012, 13, 363-368. [CrossRef]

7. Schulkes, K.J.G.; Hamaker, M.E.; van den Bos, F.; van Elden, L.J.R. Relevance of a geriatric assessment for elderly patients with lung cancer-a systematic review. Clin. Lung. Cancer 2016, 17, 341-349.e3. [CrossRef]

8. Driessen, E.J.M.; Schulkes, K.J.G.; Dingemans, A.-M.C.; van Loon, J.G.M.; Hamaker, M.E.; Aarts, M.J.; Janssen-Heijnen, M.L.G. Patterns of treatment and survival among older patients with stage III non-small cell lung cancer. Lung Cancer 2018, 116, 55-61. [CrossRef]

9. Balducci, L. Frailty: A common pathway in aging and cancer. Interdiscip. Top. Gerontol. 2013, 38, 61-72. [CrossRef]

10. Mislang, A.R.; Wildes, T.M.; Kanesvaran, R.; Baldini, C.; Holmes, H.M.; Nightingale, G.; Coolbrandt, A.; Biganzoli, L. Adherence to oral cancer therapy in older adults: The international society of geriatric oncology (SIOG) taskforce recommendations. Cancer Treat. Rev. 2017, 57, 58-66. [CrossRef]

11. Tufman, A.; Kahnert, K.; Duell, T.; Kauffmann-Guerrero, D.; Milger, K.; Schneider, C.; Stump, J.; Syunyaeva, Z.; Huber, R.M.; Reu, S. Frequency and clinical relevance of EGFR mutations and EML4-ALK translocations in octogenarians with non-small cell lung cancer. Onco Targets Ther. 2017, 10, 5179-5186. [CrossRef]

12. Enewold, L.; Thomas, A. Real-world patterns of EGFR testing and treatment with erlotinib for non-small cell lung cancer in the United States. PLoS ONE 2016, 11, e0156728. [CrossRef]

13. Barlesi, F.; Scherpereel, A.; Rittmeyer, A.; Pazzola, A.; Ferrer Tur, N.; Kim, J.-H.; Ahn, M.-J.; Aerts, J.G.J.V.; Gorbunova, V.; Vikström, A.; et al. Randomized phase III trial of maintenance bevacizumab with or without pemetrexed after first-line induction with bevacizumab, cisplatin, and pemetrexed in advanced nonsquamous non-small-cell lung cancer: AVAPERL (MO22089). J. Clin. Oncol. 2013, 31, 3004-3011. [CrossRef]

14. Fumagalli, C.; Catania, C.; Ranghiero, A.; Bosi, C.; Viale, G.; de Marinis, F.; Barberis, M.; Guerini-Rocco, E. Molecular profile of advanced non-small cell lung cancers in octogenarians: The door to precision medicine in elderly patients. J. Clin. Med. 2019, 8, 112. [CrossRef]

15. Camidge, D.R.; Kim, H.R.; Ahn, M.-J.; Yang, J.C.-H.; Han, J.-Y.; Lee, J.-S.; Hochmair, M.J.; Li, J.Y.-C.; Chang, G.-C.; Lee, K.H.; et al. Brigatinib versus crizotinib in ALK-positive non-small-cell lung cancer. N. Engl. J. Med. 2018, 379, 2027-2039. [CrossRef]

16. Peters, S.; Camidge, D.R.; Shaw, A.T.; Gadgeel, S.; Ahn, J.S.; Kim, D.-W.; Ou, S.-H.I.; Pérol, M.; Dziadziuszko, R.; Rosell, R.; et al. Alectinib versus Crizotinib in untreated ALK-positive non-small-cell lung cancer. N. Engl. J. Med. 2017, 377, 829-838. [CrossRef]

17. Soria, J.-C.; Tan, D.S.W.; Chiari, R.; Wu, Y.-L.; Paz-Ares, L.; Wolf, J.; Geater, S.L.; Orlov, S.; Cortinovis, D.; Yu, C.-J.; et al. First-line ceritinib versus platinum-based chemotherapy in advanced alk-rearranged non-small-cell lung cancer (ASCEND-4): A randomised, open-label, phase 3 study. Lancet 2017, 389, 917-929. [CrossRef]

18. Solomon, B.J.; Mok, T.; Kim, D.-W.; Wu, Y.-L.; Nakagawa, K.; Mekhail, T.; Felip, E.; Cappuzzo, F.; Paolini, J.; Usari, T.; et al. First-line crizotinib versus chemotherapy in ALK-positive lung cancer. N. Engl. J. Med. 2014, 371, 2167-2177. [CrossRef]

19. Frampton, G.M.; Ali, S.M.; Rosenzweig, M.; Chmielecki, J.; Lu, X.; Bauer, T.M.; Akimov, M.; Bufill, J.A.; Lee, C.; Jentz, D.; et al. Activation of MET via diverse exon 14 splicing alterations occurs in multiple tumor types and confers clinical sensitivity to MET inhibitors. Cancer Discov. 2015, 5, 850-859. [CrossRef]

20. Awad, M.M.; Leonardi, G.C.; Kravets, S.; Dahlberg, S.E.; Drilon, A.; Noonan, S.A.; Camidge, D.R.; Ou, S.-H.I.; Costa, D.B.; Gadgeel, S.M.; et al. Impact of MET inhibitors on survival among patients with non-small cell lung cancer harboring MET Exon 14 mutations: A retrospective analysis. Lung Cancer 2019, 133, 96-102. [CrossRef]

21. Drilon, A.E.; Camidge, D.R.; Ou, S.-H.I.; Clark, J.W.; Socinski, M.A.; Weiss, J.; Riely, G.J.; Winter, M.; Wang, S.C.; Monti, K.; et al. Efficacy and safety of crizotinib in patients (Pts) with advanced MET exon 14-altered non-small cell lung cancer (NSCLC). J. Clin. Oncol. 2016, 34, 108. [CrossRef]

22. Couraud, S.; Westeel, V.; Ranchon, F.; Toffart, A.-C.; Souquet, P.J. Comité de Rédaction des Référentiels Auvergne Rhône-Alpes en; Oncologie Thoracique; Comité de Rédaction de L'édition 2021 Référentiel sur le Cancer Bronchique non à Petites-Cellules: Actualisation 2021; ARISTOT: Paris, France, 2021.

23. La Valeur de L'outil « Risque de Biais » de la Cochrane Collaboration Dans les Synthèses Méthodiques. Available online: http:/ / www.minerva-ebm.be/FR/Article/2109 (accessed on 12 August 2021).

24. Preferred Reporting Items for Systematic Reviews and Meta-Analyses: The PRISMA Statement. Available online: https: / /journals.plos.org/plosmedicine/article?id=10.1371/journal.pmed.1000097 (accessed on 12 August 2021).

25. Haute Autorité de Santé. Etat des Lieux-Niveau de Preuve et Gradation des Recommandations de Bonne Pratique; Haute Autorité de Santé: Saint-Denis La Plaine Cedex, France, 2013; ISBN 978-2-11-138037-0.

26. Tanaka, H.; Taima, K.; Tanaka, Y.; Itoga, M.; Ishioka, Y.; Nakagawa, H.; Baba, K.; Hasegawa, Y.; Takanashi, S.; Tasaka, S. A Phase I study of afatinib for patients aged 75 or older with advanced non-small cell lung cancer harboring EGFR mutations. Med. Oncol. 2018, 35, 1-6. [CrossRef] [PubMed] 
27. Imai, H.; Kaira, K.; Suzuki, K.; Anzai, M.; Tsuda, T.; Ishizuka, T.; Kuwako, T.; Naruse, I.; Nemoto, K.; Uchino, J.; et al. A phase II study of afatinib treatment for elderly patients with previously untreated advanced non-small-cell lung cancer harboring EGFR mutations. Lung Cancer 2018, 126, 41-47. [CrossRef] [PubMed]

28. Minegishi, Y.; Yamaguchi, O.; Sugawara, S.; Kuyama, S.; Watanabe, S.; Usui, K.; Mori, M.; Hataji, O.; Nukiwa, T.; Morita, S.; et al. A phase II study of first-line afatinib for patients aged $\geq 75$ years with EGFR mutation-positive advanced non-small cell lung cancer: North east japan study group trial NEJ027. BMC Cancer 2021, 21, 208. [CrossRef] [PubMed]

29. Tateishi, K.; Ichiyama, T.; Hirai, K.; Agatsuma, T.; Koyama, S.; Hachiya, T.; Morozumi, N.; Shiina, T.; Koizumi, T. Clinical outcomes in elderly patients administered gefitinib as first-line treatment in epidermal growth factor receptor-mutated non-small-cell lung cancer: Retrospective analysis in a nagano lung cancer research group study. Med. Oncol. 2013, 30, 1-6. [CrossRef]

30. Fujita, S.; Katakami, N.; Masago, K.; Yoshioka, H.; Tomii, K.; Kaneda, T.; Hirabayashi, M.; Kunimasa, K.; Morizane, T.; Mio, T. Customized chemotherapy based on epidermal growth factor receptormutation status for elderly patients with advanced non-small-cell lung cancer: A phase II trial. BMC Cancer 2012, 12, 185. [CrossRef]

31. Morikawa, N.; Minegishi, Y.; Inoue, A.; Maemondo, M.; Kobayashi, K.; Sugawara, S.; Harada, M.; Hagiwara, K.; Okinaga, S.; Oizumi, S.; et al. First-line gefitinib for elderly patients with advanced NSCLC harboring EGFR mutations. A combined analysis of North-East Japan Study Group studies. Expert Opin. Pharmacother. 2015, 16, 465-472. [CrossRef]

32. Maemondo, M.; Minegishi, Y.; Inoue, A.; Kobayashi, K.; Harada, M.; Okinaga, S.; Morikawa, N.; Oizumi, S.; Tanaka, T.; Isobe, H.; et al. First-line gefitinib in patients aged 75 or older with advanced non-small cell lung cancer harboring epidermal growth factor receptor mutations: NEJ 003 study. J. Thorac. Oncol. 2012, 7, 1417-1422. [CrossRef]

33. Takahashi, K.; Saito, H.; Hasegawa, Y.; Ando, M.; Yamamoto, M.; Kojima, E.; Sugino, Y.; Kimura, T.; Nomura, F.; Ogasawara, T.; et al. First-line gefitinib therapy for elderly patients with non-small cell lung cancer harboring EGFR mutation: Central Japan lung study group 0901. Cancer Chemother. Pharmacol. 2014, 74, 721-727. [CrossRef]

34. Kuwako, T.; Imai, H.; Masuda, T.; Miura, Y.; Seki, K.; Yoshino, R.; Kaira, K.; Utsugi, M.; Shimizu, K.; Sunaga, N.; et al. First-line gefitinib treatment in elderly patients (Aged $\geq 75$ Years) with non-small cell lung cancer harboring EGFR mutations. Cancer Chemother. Pharmacol. 2015, 76, 761-769. [CrossRef]

35. Asami, K.; Koizumi, T.; Hirai, K.; Ameshima, S.; Tsukadaira, A.; Morozumi, N.; Morikawa, A.; Atagi, S.; Kawahara, M. Gefitinib as first-line treatment in elderly epidermal growth factor receptor-mutated patients with advanced lung adenocarcinoma: Results of a nagano lung cancer research group study. Clin. Lung Cancer 2011, 12, 387-392. [CrossRef]

36. Corre, R.; Gervais, R.; Guisier, F.; Tassy, L.; Vinas, F.; Lamy, R.; Fraboulet, G.; Greillier, L.; Doubre, H.; Descourt, R.; et al. Octogenarians with EGFR-mutated non-small cell lung cancer treated by tyrosine-kinase inhibitor: A multicentric real-world study assessing tolerance and efficacy (OCTOMUT Study). Oncotarget 2018, 9, 8253-8262. [CrossRef]

37. Furuta, H.; Uemura, T.; Yoshida, T.; Kobara, M.; Yamaguchi, T.; Watanabe, N.; Shimizu, J.; Horio, Y.; Kuroda, H.; Sakao, Y.; et al. Efficacy and safety data of osimertinib in elderly patients with NSCLC who harbor the EGFR T790M mutation after failure of initial EGFR-TKI treatment. Anticancer Res. 2018, 38, 5231-5237. [CrossRef]

38. Nakao, A.; Hiranuma, O.; Uchino, J.; Sakaguchi, C.; Araya, T.; Hiraoka, N.; Ishizuka, T.; Takeda, T.; Kawasaki, M.; Goto, Y.; et al. Final results from a phase II trial of osimertinib for elderly patients with epidermal growth factor receptor T790m-positive non-small cell lung cancer that progressed during previous treatment. J. Clin. Med. 2020, 9, 1762. [CrossRef]

39. Auliac, J.B.; Saboundji, K.; Andre, M.; Madelaine, J.; Quere, G.; Masson, P.; Vergnenegre, A.; Lamy, R.; Raymond, S.; Chiappa, A.M.; et al. Real-life efficacy of osimertinib in pretreated octogenarian patients with T790M-mutated advanced non-small cell lung cancer. Target. Oncol. 2019, 14, 307-314. [CrossRef]

40. Kato, Y.; Hosomi, Y.; Watanabe, K.; Yomota, M.; Kawai, S.; Okuma, Y.; Kubota, K.; Seike, M.; Gemma, A.; Okamura, T. Impact of clinical features on the efficacy of osimertinib therapy in patients with T790M-positive non-small cell lung cancer and acquired resistance to epidermal growth factor receptor tyrosine kinase inhibitors. J. Thorac. Dis. 2019, 11, 2350-2360. [CrossRef]

41. Miyamoto, S.; Azuma, K.; Ishii, H.; Bessho, A.; Hosokawa, S.; Fukamatsu, N.; Kunitoh, H.; Ishii, M.; Tanaka, H.; Aono, H.; et al. Low-dose erlotinib treatment in elderly or frail patients with EGFR mutation-positive non-small cell lung cancer: A multicenter phase 2 trial. JAMA Oncol. 2020, 6, e201250. [CrossRef]

42. Inoue, Y.; Inui, N.; Asada, K.; Karayama, M.; Matsuda, H.; Yokomura, K.; Koshimizu, N.; Imokawa, S.; Yamada, T.; Shirai, T.; et al. Phase II study of erlotinib in elderly patients with non-small cell lung cancer harboring epidermal growth factor receptor mutations. Cancer Chemother. Pharmacol. 2015, 76, 155-161. [CrossRef]

43. Park, K.; Tan, E.-H.; O’Byrne, K.; Zhang, L.; Boyer, M.; Mok, T.; Hirsh, V.; Yang, J.C.-H.; Lee, K.H.; Lu, S.; et al. Afatinib versus Gefitinib as First-Line Treatment of Patients with EGFR Mutation-Positive Non-Small-Cell Lung Cancer (LUX-Lung 7): A Phase 2B, Open-Label, Randomised Controlled Trial. Lancet Oncol 2016, 17, 577-589. [CrossRef]

44. Wu, Y.L.; Sequist, L.V.; Tan, E.H.; Geater, S.L.; Orlov, S.; Zhang, L.; Lee, K.H.; Tsai, C.M.; Kato, T.; Barrios, C.H.; et al. Afatinib as first-line treatment of older patients with EGFR mutation-positive non-small-cell lung cancer: Subgroup analyses of the LUX-lung 3, LUX-lung 6, and LUX-lung 7 lrials. Clin. Lung Cancer 2018, 19, e465-e479. [CrossRef]

45. Sequist, L.V.; Yang, J.C.-H.; Yamamoto, N.; O’Byrne, K.; Hirsh, V.; Mok, T.; Geater, S.L.; Orlov, S.; Tsai, C.-M.; Boyer, M.; et al. Phase III study of afatinib or cisplatin plus pemetrexed in patients with metastatic lung adenocarcinoma with EGFR Mutations. J. Clin. Oncol. 2013, 31, 3327-3334. [CrossRef] 
46. Wu, Y.-L.; Cheng, Y.; Zhou, X.; Lee, K.H.; Nakagawa, K.; Niho, S.; Tsuji, F.; Linke, R.; Rosell, R.; Corral, J.; et al. Dacomitinib versus gefitinib as first-line treatment for patients with EGFR-mutation-positive non-small-cell lung cancer (ARCHER 1050): A randomised, open-label, phase 3 trial. Lancet Oncol. 2017, 18, 1454-1466. [CrossRef]

47. Zhou, C.; Wu, Y.-L.; Chen, G.; Feng, J.; Liu, X.-Q.; Wang, C.; Zhang, S.; Wang, J.; Zhou, S.; Ren, S.; et al. Erlotinib versus chemotherapy as first-line treatment for patients with advanced EGFR mutation-positive non-small-cell lung cancer (OPTIMAL, CTONG-0802): A multicentre, open-label, randomised, phase 3 study. Lancet Oncol. 2011, 12, 735-742. [CrossRef]

48. Rosell, R.; Carcereny, E.; Gervais, R.; Vergnenegre, A.; Massuti, B.; Felip, E.; Palmero, R.; Garcia-Gomez, R.; Pallares, C.; Sanchez, J.M.; et al. Erlotinib versus standard chemotherapy as first-line treatment for European patients with advanced EGFR mutation-positive non-small-cell lung cancer (EURTAC): A multicentre, open-label, randomised phase 3 trial. Lancet Oncol. 2012, 13, 239-246. [CrossRef]

49. Soria, J.-C.; Ohe, Y.; Vansteenkiste, J.; Reungwetwattana, T.; Chewaskulyong, B.; Lee, K.H.; Dechaphunkul, A.; Imamura, F.; Nogami, N.; Kurata, T.; et al. Osimertinib in untreatedEGFR-mutated advanced non-small-cell lung cancer. N. Engl. J. Med. 2018, 378, 113-125. [CrossRef]

50. Ramalingam, S.S.; Vansteenkiste, J.; Planchard, D.; Cho, B.C.; Gray, J.E.; Ohe, Y.; Zhou, C.; Reungwetwattana, T.; Cheng, Y.; Chewaskulyong, B.; et al. Overall survival with osimertinib in untreated, EGFR-mutated advanced NSCLC. N. Engl. J. Med. 2020, 382, 41-50. [CrossRef]

51. Mok, T.S.; Wu, Y.-L.; Ahn, M.-J.; Garassino, M.C.; Kim, H.R.; Ramalingam, S.S.; Shepherd, F.A.; He, Y.; Akamatsu, H.; Theelen, W.S.M.E.; et al. Osimertinib or platinum-pemetrexed in EGFR T790M-positive lung cancer. N. Engl. J. Med. 2017, 376, 629-640. [CrossRef]

52. Douillard, J.-Y.; Ostoros, G.; Cobo, M.; Ciuleanu, T.; McCormack, R.; Webster, A.; Milenkova, T. First-line gefitinib in caucasian EGFR mutation-positive NSCLC patients: A phase-IV, open-label, single-arm study. Br. J. Cancer. 2014, 110, 55-62. [CrossRef]

53. Paz-Ares, L.; Tan, E.-H.; O’Byrne, K.; Zhang, L.; Hirsh, V.; Boyer, M.; Yang, J.C.-H.; Mok, T.; Lee, K.H.; Lu, S.; et al. Afatinib versus gefitinib in patients with EGFR mutation-positive advanced non-small-cell lung cancer: Overall survival data from the phase IIb LUX-lung 7 trial. Ann. Oncol. 2017, 28, 270-277. [CrossRef]

54. Hida, T.; Nokihara, H.; Kondo, M.; Kim, Y.H.; Azuma, K.; Seto, T.; Takiguchi, Y.; Nishio, M.; Yoshioka, H.; Imamura, F.; et al. Alectinib versus crizotinib in patients with ALK-positive non-small-cell lung cancer (J-ALEX): An open-label, randomised phase 3 trial. Lancet 2017, 390, 29-39. [CrossRef]

55. Bedas, A.; Peled, N.; Maimon Rabinovich, N.; Mishaeli, M.; Shochat, T.; Zer, A.; Rotem, O.; Allen, A.M.; Bar, J.; Dudnik, E. Efficacy and safety of ALK tyrosine kinase inhibitors in elderly patients with advanced ALK-positive non-small cell lung cancer: Findings from the real-life cohort. Oncol. Res. Treat. 2019, 42, 275-282. [CrossRef]

56. Camidge, D.R.; Bang, Y.-J.; Kwak, E.L.; Iafrate, A.J.; Varella-Garcia, M.; Fox, S.B.; Riely, G.J.; Solomon, B.; Ou, S.-H.I.; Kim, D.-W.; et al. Activity and safety of crizotinib in patients with ALK-positive non-small-cell lung cancer: Updated results from a phase 1 study. Lancet Oncol. 2012, 13, 1011-1019. [CrossRef]

57. Wu, Y.-L.; Yang, J.C.-H.; Kim, D.-W.; Lu, S.; Zhou, J.; Seto, T.; Yang, J.-J.; Yamamoto, N.; Ahn, M.-J.; Takahashi, T.; et al. Phase II study of crizotinib in east asian patients with ROS1-positive advanced non-small-cell lung cancer. J. Clin. Oncol. 2018, 36, 1405-1411. [CrossRef]

58. Inomata, M.; Shimokawa, K.; Tokui, K.; Taka, C.; Okazawa, S.; Kambara, K.; Yamada, T.; Miwa, T.; Hayashi, R.; Kashii, T.; et al. Appetite loss as an adverse effect during treatment with EGFR-Tkis in elderly patients with non-small cell lung cancer. Anticancer Res. 2016, 36, 4951-4954. [CrossRef]

59. Wu, C.-H.; Fan, W.-C.; Chen, Y.-M.; Chou, K.-T.; Shih, J.-F.; Tsai, C.-M.; Lee, Y.-C.; Perng, R.-P. Second-line therapy for elderly patients with non-small cell lung cancer who failed previous chemotherapy is as effective as for younger patients. J. Thorac. Oncol. 2010, 5, 376-379. [CrossRef]

60. Nakao, A.; Hiranuma, O.; Uchino, J.; Sakaguchi, C.; Kita, T.; Hiraoka, N.; Ishizuka, T.; Kubota, Y.; Kawasaki, M.; Goto, Y.; et al. Osimertinib in elderly patients with epidermal growth factor receptor T790M-positive non-small-cell lung cancer who progressed during prior treatment: A phase II trial. Oncologist 2019, 24, 593-e170. [CrossRef]

61. Minemura, H.; Yokouchi, H.; Azuma, K.; Hirai, K.-I.; Sekine, S.; Oshima, K.; Kanazawa, K.; Tanino, Y.; Inokoshi, Y.; Ishii, T.; et al. A phase II trial of erlotinib monotherapy for pretreated elderly patients with advanced EGFR wild-type non-small cell lung cancer cancer. BMC Res. Notes 2015, 8, 1-6. [CrossRef]

62. Rossi, D.; Dennetta, D.; Ugolini, M.; Catalano, V.; Alessandroni, P.; Giordani, P.; Baldelli, A.M.; Casadei, V.; Graziano, F.; Fedeli, S.L. Activity and safety of erlotinib as second- and third-line treatment in elderly patients with advanced non-small cell lung cancer: A phase II trial. Target. Oncol. 2010, 5, 231-235. [CrossRef]

63. Yoshioka, H.; Komuta, K.; Imamura, F.; Kudoh, S.; Seki, A.; Fukuoka, M. Efficacy and safety of erlotinib in elderly patients in the phase IV POLARSTAR surveillance study of japanese patients with non-small-cell lung cancer. Lung Cancer 2014, 86, 201-206. [CrossRef]

64. Brueckl, W.M.; Achenbach, H.J.; Ficker, J.H.; Schuette, W. Erlotinib treatment after platinum-based therapy in elderly patients with non-small-cell lung cancer in routine clinical practice-Results from the ElderTac study. BMC Cancer 2018, 18, 333. [CrossRef]

65. Yamada, K.; Azuma, K.; Takeshita, M.; Uchino, J.; Nishida, C.; Suetsugu, T.; Kondo, A.; Harada, T.; Eida, H.; Kishimoto, J.; et al. Phase II trial of erlotinib in elderly patients with previously treated non-small cell lung cancer: Results of the lung oncology group in kyushu (LOGiK-0802). Anticancer Res. 2016, 36, 2881-2887. 
66. Aoshima, Y.; Karayama, M.; Inui, N.; Yasui, H.; Hozumi, H.; Suzuki, Y.; Furuhashi, K.; Fujisawa, T.; Enomoto, N.; Nakamura, Y.; et al. Erlotinib and bevacizumab in elderly patients $\geq 75$ years old with non-small cell lung cancer harboring epidermal growth factor receptor mutations. Invest. New Drugs 2021, 39, 210-216. [CrossRef]

67. Kobayashi, M.; Matsui, K.; Katakami, N.; Takeda, K.; Moriyama, A.; Iwamoto, Y.; Takada, M.; Yoshioka, H.; Sueoka-Aragane, N.; Nakagawa, K. Phase II study of gefitinib as a first-line therapy in elderly patients with pulmonary adenocarcinoma: West japan thoracic oncology group study 0402. Jpn. J. Clin. Oncol. 2011, 41, 948-952. [CrossRef]

68. Heigener, D.; Deppermann, K.; Pawel, J.; Fischer, J.; Kortsik, C.; Bohnet, S.; Eiff, M.; Koester, W.; Thomas, M.; Schnabel, P.; et al. Open, randomized, multi-center phase II study comparing efficacy and tolerability of Erlotinib vs. Carboplatin/Vinorelbin in elderly patients (>70 years of age) with untreated non-small cell lung cancer. Lung Cancer 2014, 84, 62-66. [CrossRef]

69. Chen, Y.-M.; Tsai, C.-M.; Fan, W.-C.; Shih, J.-F.; Liu, S.-H.; Wu, C.-H.; Chou, T.-Y.; Lee, Y.-C.; Perng, R.-P.; Whang-Peng, J. Phase II Randomized Trial of Erlotinib or Vinorelbine in Chemonaive, Advanced, Non-small Cell Lung Cancer Patients Aged 70 Years or Older. J. Thorac. Oncol. 2012, 7, 412-418. [CrossRef]

70. Gridelli, C.; Morgillo, F.; Favaretto, A.; de Marinis, F.; Chella, A.; Cerea, G.; Mattioli, R.; Tortora, G.; Rossi, A.; Fasano, M.; et al. Sorafenib in combination with erlotinib or with gemcitabine in elderly patients with advanced non-small-cell lung cancer: A randomized phase II study. Ann. Oncol. 2011, 22, 1528-1534. [CrossRef]

71. Quoix, E.; Westeel, V.; Moreau, L.; Pichon, E.; Lavolé, A.; Dauba, J.; Debieuvre, D.; Souquet, P.J.; Bigay-Game, L.; Dansin, E.; et al. Second-line therapy in elderly patients with advanced nonsmall cell lung cancer. Eur. Respir. J. 2014, 43, 240-249. [CrossRef]

72. Merimsky, O.; Cheng, C.-K.; Au, J.S.-K.; Von Pawel, J.; Reck, M. Efficacy and safety of first-line erlotinib in elderly patients with advanced non-small cell lung cancer. Oncol. Rep. 2012, 28, 721-727. [CrossRef]

73. Kurishima, K.; Satoh, H.; Kaburagi, T.; Nishimura, Y.; Shinohara, Y.; Inagaki, M.; Endo, T.; Saito, T.; Hayashihara, K.; Hizawa, N.; et al. Erlotinib for elderly patients with non-small-cell lung cancer: Subset analysis from a population-based observational study by the ibaraki thoracic integrative (POSITIVE) research group. Mol. Clin. Oncol. 2013, 1, 828-832. [CrossRef]

74. Tam, T.C.-C.; Ho, J.C.-M.; Wong, M.K.-Y.; Wong, W.-M.; Wang, J.K.-L.; Lam, J.C.-M.; Lui, M.M.-S.; Lam, W.-K.; Ip, M.S.-M.; Lam, D.C.-L. Treatment outcomes in elderly with advanced-stage non-small cell lung cancer. Lung 2013, 191, 645-654. [CrossRef]

75. Stinchcombe, T.E.; Roder, J.; Peterman, A.H.; Grigorieva, J.; Lee, C.B.; Moore, D.T.; Socinski, M.A. A retrospective analysis of veristrat status on outcome of a randomized phase II trial of first-line therapy with gemcitabine, erlotinib, or the combination in elderly patients (age 70 years or older) with stage IIIB/IV non-small-cell lung cancer. J. Thorac. Oncol. 2013, 8, 443-451. [CrossRef]

76. Stinchcombe, T.E.; Peterman, A.H.; Lee, C.B.; Moore, D.T.; Beaumont, J.L.; Bradford, D.S.; Bakri, K.; Taylor, M.; Crane, J.M.; Schwartz, G.; et al. A randomized phase ii trial of first-line treatment with gemcitabine, erlotinib, or gemcitabine and erlotinib in elderly patients (age $\geq 70$ years) with stage IIIB/IV non-small cell lung cancer. J. Thorac. Oncol. 2011, 6, 1569-1577. [CrossRef] [PubMed]

77. Shariati, M.; Meric-Bernstam, F. Targeting AKT for cancer therapy. Expert Opin. Investig. Drugs 2019, 28, 977-988. [CrossRef] [PubMed]

78. Li, F.; Zhao, C.; Wang, L. Molecular-targeted agents combination therapy for cancer: Developments and potentials. Int. J. Cancer 2014, 134, 1257-1269. [CrossRef] [PubMed]

79. Soubeyran, P.; Bellera, C.; Goyard, J.; Heitz, D.; Curé, H.; Rousselot, H.; Albrand, G.; Servent, V.; Jean, O.S.; van Praagh, I.; et al. Screening for vulnerability in older cancer patients: The ONCODAGE prospective multicenter cohort study. PLoS ONE 2014, 9, e115060. [CrossRef]

80. Guigoz, Y.; Vellas, B. The Mini Assessment (MNA) for grading the nutritional state of elderly patients: Presentation of the MNA, history and validation. Nestle Nutr. Workshop Ser. Clin. Perform. Programme 1999, 1, 3-11, discussion 11-12. [CrossRef]

81. Mohile, S.G.; Dale, W.; Somerfield, M.R.; Schonberg, M.A.; Boyd, C.M.; Burhenn, P.S.; Canin, B.; Cohen, H.J.; Holmes, H.M.; Hopkins, J.O.; et al. practical assessment and management of vulnerabilities in older patients receiving chemotherapy: ASCO guideline for geriatric oncology. J. Clin. Oncol. 2018, 36, 2326-2347. [CrossRef]

82. Katz, S.; Ford, A.B.; Moskowitz, R.W.; Jackson, B.A.; Jaffe, M.W. Studies of illness in the aged. The index of ADL: A standardized measure of biological and psychosocial function. J. Am. Med. Assoc. 1963, 185, 914-919. [CrossRef]

83. Charlson, M.E.; Pompei, P.; Ales, K.L.; MacKenzie, C.R. A new method of classifying prognostic comorbidity in longitudinal studies: Development and validation. J. Chronic Dis. 1987, 40, 373-383. [CrossRef]

84. Miller, M.D.; Paradis, C.F.; Houck, P.R.; Mazumdar, S.; Stack, J.A.; Rifai, A.H.; Mulsant, B.; Reynolds, C.F. Rating chronic medical illness burden in geropsychiatric practice and research: Application of the cumulative illness rating scale. Psychiatry Res. 1992, 41, 237-248. [CrossRef] 